\title{
Driving assessment for maintaining mobility and safety in drivers with dementia (Review)
}

Martin AJ, Marottoli R, O'Neill D

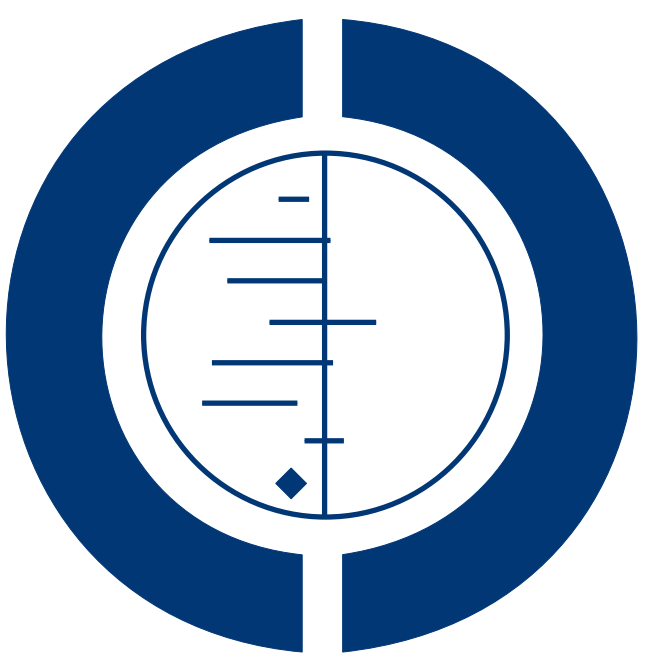

THE COCHRANE
COLLABORATION $^{\circledR}$

This is a reprint of a Cochrane review, prepared and maintained by The Cochrane Collaboration and published in The Cochrane Library 2013, Issue 5

http://www.thecochranelibrary.com

\section{WILEY}

Driving assessment for maintaining mobility and safety in drivers with dementia (Review)

Copyright $\odot 2013$ The Cochrane Collaboration. Published by John Wiley \& Sons, Ltd. 
TABLE OF CONTENTS

HEADER . . . . . . . . . . . . . . . . . . . . . . . . . . . . . . . . . . . . 1

ABSTRACT . . . . . . . . . . . . . . . . . . . . . . . . . . . . . . . . . . . . . . . . . . . . . . .

PLAIN LANGUAGE SUMMARY . . . . . . . . . . . . . . . . . . . . . . . . . . . . . . . . . . . 2

BACKGROUND . . . . . . . . . . . . . . . . . . . . . . . . . . . . . . . . . . . . . . . . .

OBJECTIVES . . . . . . . . . . . . . . . . . . . . . . . . . . . . . . . . . . . . . .

METHODS . . . . . . . . . . . . . . . . . . . . . . . . . . . . . . . . . . . . . . .

RESULTS . . . . . . . . . . . . . . . . . . . . . . . . . . . . . . . . . . . . . . . 4

DISCUSSION . . . . . . . . . . . . . . . . . . . . . . . . . . . . . . . . . . . . . 4.4

AUTHORS' CONCLUSIONS . . . . . . . . . . . . . . . . . . . . . . . . . . . . . . . . . . . . 9.9

ACKNOWLEDGEMENTS . . . . . . . . . . . . . . . . . . . . . . . . . . . . . . . . . . 9

REFERENCES . . . . . . . . . . . . . . . . . . . . . . . . . . . . . . . . . . . . . . 10

CHARACTERISTICS OF STUDIES . . . . . . . . . . . . . . . . . . . . . . . . . . . . . . . . . . . . .

DATA AND ANALYSES . . . . . . . . . . . . . . . . . . . . . . . . . . . . . . . . . . . . . . . . . . . . . . . . . . .

APPENDICES . . . . . . . . . . . . . . . . . . . . . . . . . . . . . . . . . . . . 26

WHAT'S NEW . . . . . . . . . . . . . . . . . . . . . . . . . . . . . . . . . . . . . . 31

CONTRIBUTIONS OF AUTHORS . . . . . . . . . . . . . . . . . . . . . . . . . . . . . . . . . 32

DECLARATIONS OF INTEREST . . . . . . . . . . . . . . . . . . . . . . . . . . . . . . . . . 32

SOURCES OF SUPPORT . . . . . . . . . . . . . . . . . . . . . . . . . . . . . . . . . . 32

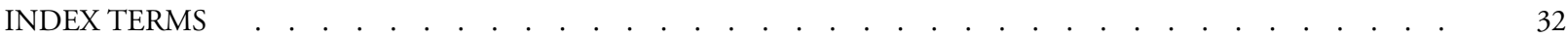

Driving assessment for maintaining mobility and safety in drivers with dementia (Review)

Copyright @ 2013 The Cochrane Collaboration. Published by John Wiley \& Sons, Ltd. 


\title{
[Intervention Review] \\ Driving assessment for maintaining mobility and safety in drivers with dementia
}

\author{
Alan J Martin ${ }^{1}$, Richard Marottoli ${ }^{2}$, Desmond O’Neill ${ }^{3}$ \\ ${ }^{1}$ Department of Geriatric and Stroke Medicine, Beaumont Hospital, Dublin 9, Ireland. ${ }^{2}$ Division of Geriatrics, Yale University, New \\ Haven, USA. ${ }^{3}$ Centre for Ageing, Neuroscience and the Humanities, Trinity College Dublin, Dublin, Ireland \\ Contact address: Alan J Martin, Department of Geriatric and Stroke Medicine, Beaumont Hospital, Beaumont Road, Dublin 9, Ireland. \\ alanmartin@physicians.ie.
}

Editorial group: Cochrane Dementia and Cognitive Improvement Group.

Publication status and date: New search for studies and content updated (no change to conclusions), published in Issue 5, 2013.

Review content assessed as up-to-date: 12 March 2013.

Citation: Martin AJ, Marottoli R, O’Neill D. Driving assessment for maintaining mobility and safety in drivers with dementia. Cochrane Database of Systematic Reviews 2013, Issue 5. Art. No.: CD006222. DOI: 10.1002/14651858.CD006222.pub3.

Copyright (C) 2013 The Cochrane Collaboration. Published by John Wiley \& Sons, Ltd.

\begin{abstract}
A B S T R A C T

\section{Background}

Demographic changes are leading to an increase in the number of older drivers: as dementia is an age-related disease, there is also an increase in the numbers of drivers with dementia. Dementia can impact on both the mobility and safety of drivers, and the impact of formal assessment of driving is unknown in terms of either mobility or safety. Those involved in assessment of older drivers need to be aware of the evidence of positive and negative effects of driving assessment. Cognitive tests are felt by some authors to have poor face and construct validity for assessing driving performance; extrapolating from values in one large-scale prospective cohort study, the cognitive test that most strongly predicted future crashes would, if used as a screening tool, potentially prevent six crashes per 1000 people over 65 years of age screened, but at the price of stopping the driving of 121 people who would not have had a crash.
\end{abstract}

\section{Objectives}

Primary objectives:

1. to assess whether driving assessment facilitates continued driving in people with dementia;

2. to assess whether driving assessment reduces accidents in people with dementia.

Secondary objective:

1. to assess the quality of research on assessment of drivers with dementia.

\section{Search methods}

ALOIS, the Cochrane Dementia Group's Specialized Register was searched on 13 September 2012 using the terms: driving or driver* or "motor vehicle*" or "car accident" or "traffic accident" or automobile* or traffic. This register contains records from major healthcare databases, ongoing trial databases and grey literature sources and is updated regularly.

\section{Selection criteria}

We sought randomised controlled trials prospectively evaluating drivers with dementia for outcomes such as transport mobility, driving cessation or motor vehicle accidents following driving assessment.

Driving assessment for maintaining mobility and safety in drivers with dementia (Review)

Copyright @ 2013 The Cochrane Collaboration. Published by John Wiley \& Sons, Ltd. 


\section{Data collection and analysis}

Each review author retrieved studies and assessed for primary and secondary outcomes, study design and study quality.

\section{Main results}

No studies were found that met the inclusion criteria. A description and discussion of the driving literature relating to assessment of drivers with dementia relating to the primary objectives is presented.

\section{Authors' conclusions}

In an area with considerable public health impact for drivers with dementia and other road users, the available literature fails to demonstrate the benefit of driver assessment for either preserving transport mobility or reducing motor vehicle accidents. Driving legislation and recommendations from medical practitioners requires further research that addresses these outcomes in order to provide the best outcomes for both drivers with dementia and the general public.

\section{PLAIN LANGUAGE SUMMARY}

\section{Driving assessment for maintaining mobility and safety in drivers with dementia}

The proportion of older people in the world is increasing and consequently the number of older drivers is also on the rise. Older people commonly depend upon private motor vehicles for their transport needs and so assessment of older drivers with cognitive impairment is becoming increasingly important. We have reviewed the literature on driving assessment in people with dementia for two reasons. First, we wished to see if assessment helped people with dementia and good driving skills continue driving. Second, we wished to discover whether assessment was useful in preventing road traffic accidents.

Although many authors have studied the motor skills, neuropsychological performance and driving behaviour of drivers with dementia, we found no study that randomised drivers to evaluate these outcomes prospectively following assessment. This highlights the need for caution in applying the literature on driving assessment to clinical settings as no benefit has yet been prospectively demonstrated. It also indicates the need for prospective evaluation of new and existing models of driver assessment to best preserve transport mobility and minimise road traffic accidents.

\section{B A C K G R O U N D}

With an increasingly aged population, the number of older drivers is on the increase. Driving is the most common form of transport for older people, with only $3 \%$ of journeys by older people in the US undertaken by public transport. Transport and access to transport is an important factor in maintaining social inclusion and participation for older people: there is also considerable evidence that limiting this access (i.e. by driving cessation) is associated with poor health and depression (Marottoli 2000). Exclusion of elderly people from driving has been demonstrated to have many negative effects: loneliness, lower life satisfaction and lower activity levels. Drivers with dementia limit their driving and eventually withdraw, with profound negative effects on their mobility (Taylor 2001).

We do not know what interventions will maintain safe mobility for the longest period for people with dementia. A full assessment (often including an on-road assessment) may have beneficial effects for drivers with many illnesses apart from dementia (Stutts 2003), and restricted driving licenses following assessment for people with medical conditions other than dementia are associated with a lower crash risk (Vernon 2002). An assessment in dementia also allows for advance planning of driving withdrawal and substitution of other transportation modalities, by way of the so-called modified Ulysses pact (Robinson 2004). It also allow for regular re-testing to guide this process (Duchek 2003).

Although there is no standardised neuropsychological assessment battery, most driving assessment protocols include medical, occupational therapy, neuropsychology assessment, or a combination of these, and an on-road driving assessment as required. We have no evidence that this intervention enhances either mobility or safety in people with dementia. 
We sought evidence that formalised driving assessments are effective in maintaining mobility and safety in drivers with dementia rather than merely excluding those who are unfit to drive. Continued driving and outdoor mobility is important to older people and is a sufficient outcome measure in its own right. Safety is arguably a secondary end point, as crashes are relatively infrequent events, and fatal crashes even more so (1 per 50 million $\mathrm{km}$ ). RCTs of driving assessment should involve a careful design, randomising people who drive to either formal testing or usual care and assessment, with longitudinal follow-up of satisfaction with transport (Rosenbloom 2003) and crashes or violations.

\section{O B J E C T I V E S}

Primary objectives:

- to assess whether driving assessment facilitates continued driving in people with dementia;

- to assess whether driving assessment reduces accidents in people with dementia.

Secondary objective:

- to assess the quality of research on assessment of drivers with dementia.

\section{METHODS}

\section{Criteria for considering studies for this review}

\section{Types of studies}

All relevant randomised controlled trials (RCTs) were included. Non-randomised trials (N-RCTs) are discussed in the Background and Discussion sections as appropriate. N-RCTs were excluded from the meta-analysis.

\section{Types of participants}

People with dementia of any type, without age restriction, were included.

\section{Types of interventions}

Any formal on-road driving assessment. The driving assessment may also involve standardised neuropsychological assessment battery, medical or occupational therapy assessment, but the intervention that is randomised should include formal on-road assessment.

\section{Types of outcome measures}

Our primary outcome was the number of people who remain driving after assessment compared to the control or placebo group. A second primary outcome was the number of road traffic accidents (RTAs) after assessment.

\section{Search methods for identification of studies}

\section{Electronic searches}

We searched ALOIS (www.medicine.ox.ac.uk/alois) - the Cochrane Dementia and Cognitive Improvement Group's Specialized Register on 13 September 2012. The search terms used were: driving or driver* or "motor vehicle*" or "car accident" or "traffic accident*" or automobile* or traffic.

ALOIS is maintained by the Trials Search Co-ordinator of the Cochrane Dementia and Cognitive Improvement Group and contains studies in the areas of dementia prevention, dementia treatment and cognitive enhancement in healthy. The studies are identified from:

1. monthly searches of a number of major healthcare databases: MEDLINE, EMBASE, CINAHL, PsycINFO and LILACS;

2. Monthly searches of a number of trial registers: ISRCTN; UMIN (Japan's Trial Register); the World Health Organization (WHO) portal (which covers ClinicalTrials.gov; ISRCTN; the Chinese Clinical Trials Register; the German Clinical Trials Register; the Iranian Registry of Clinical Trials and the Netherlands National Trials Register, plus others);

3. quarterly search of The Cochrane Library's Central Register of Controlled Trials (CENTRAL);

4. six-monthly searches of a number of grey literature sources: ISI Web of Knowledge Conference Proceedings; Index to Theses; Australasian Digital Theses.

To view a list of all sources searched for ALOIS see About ALOIS on the ALOIS website.

Details of the search strategies used for the retrieval of reports of trials from the healthcare databases, CENTRAL and conference proceedings can be viewed in the 'methods used in reviews' section within the editorial information about the Dementia and Cognitive Improvement Group.

Additional searches were performed in many of the sources listed above to cover the timeframe from the last searches performed for ALOIS to ensure that the search for the review was as up-to-date and as comprehensive as possible. The search strategies used can be seen in Appendix 1.

The latest search (September 2012) retrieved a total of 741 results.

\section{Data collection and analysis}


Studies were selected from lists generated by the search strategy. Hard copies of all relevant studies were retrieved. Two review authors (AM, DON), blinded with respect to study authors, institution and journal, independently assessed trial quality and extracted data from studies that met the inclusion criteria. Meta-analysis and narrative review were performed where appropriate for each of the nominated outcomes. The Review Manager (RevMan 2011) software package was used where appropriate to perform the metaanalysis for continuous and dichotomous outcome measures. NRCTs were not included in the primary analysis but are included in the discussion.

\section{Data extraction}

Data were extracted independently by two review authors (AM, DON). A data extraction form was used to record methodological and outcome data.

\section{Quality assessment}

The quality assessment of the included trials was undertaken independently and in duplicate by two review authors (AM, RM). The quality criteria that were examined are: allocation concealment (recorded as: adequate, unclear, inadequate or not used), and completeness of follow-up and intention-to-treat analysis. Given the nature of the study, blinding would not be expected.

\section{Data analysis}

No data for analysis (see Results section).

\section{RES U L T S}

\section{Description of studies}

Our first search in 2007 identified 444 titles from which 202 abstracts were reviewed and in all 63 full-text papers were reviewed. Our second search in 2012 identified an additional 122 titles from which 70 abstracts and 41 full-text papers were reviewed.

\section{Risk of bias in included studies}

There were no studies that met the inclusion criteria.

\section{Effects of interventions}

There were no studies that met the inclusion criteria.

\section{I S C U S S I O N}

The importance of transportation to health and social inclusion of older people, and in particular, older people with dementia, must be recognised. Helpful studies in this regard are Taylor 2001, which showed an unmet shortfall in transport requirement and provision for drivers with dementia who stop driving, and a public health paper by Freeman 2006, which found that after controlling for other factors, driving cessation was associated with a higher risk of entry to nursing home. This relative lack of attention to transportation may also have societal roots, as indicated by a review of newspaper articles on older drivers, whereby the overwhelming emphasis was on safety rather than mobility (Martin 2005).

A second issue arises from a failure, as yet, to incorporate modern theories of driver behaviour (Ranney 1994; Fuller 2005) into existing driver assessment procedures, which almost invariably emphasise cognitive measures. These may play a less determining role in driving efficacy in mild to moderate dementia than is commonly understood. An exception to the cognitive approach can be seen in the work of de Raedt 2000, which uses a hierarchical and behavioural approach, and which seems to show promise in offroad assessment of drivers who have been noted to require driving assessment by physicians or state authorities.

There may be other methodological difficulties encountered in carrying out driving research. Testing may be challenging for the person, as described by Snellgrove 2000 and Clark 2005, and some may choose to give up driving rather than take a test. Faced with the threat of a test, the older driver may withdraw from driving, and enter the traffic in a more dangerous capacity, that is, as a pedestrian (Hakamies-Blomqvist 1996). One study has suggested it also led to an increase in the relative number of unsafe older drivers based on an increase in crashes per license following the introduction of mandatory testing (Langford 2004). Safety, legal and ethical implications for subjects and assessors carrying out road testing can also create significant obstacles to participation and study design. With the potential for fatal crashes at stake, the tenor of the vast majority of these narratives and descriptive studies is negative - directed towards driving cessation rather than preserving and enhancing mobility - and therefore restrictive from the point of view of the consumer undergoing assessment. They tend to focus on negative outcomes, which, although serious, are, in fact, rare and in doing so reinforce a negative stereotype on a large number of older drivers with cognitive impairment. Another methodological and practical consideration influencing the types of studies available is that identifying risk factors for crashes or cessation can be accomplished by relatively easy adaptation of existing databases or cohort studies. Intervention studies are inherently more time and cost intensive. To undertake intervention studies for rare outcomes such as crashes would require large sample sizes, a prevalent risk factor to target, and a reasonably effective intervention for that risk factor.

Driving assessment for maintaining mobility and safety in drivers with dementia (Review) 
In order to appraise the available literature we approached the evidence from the point of view of the consumer and of evaluating physicians and used the following questions to illustrate what is known, what is inferred and what remains to be established.

\section{Will assessment maintain transport mobility?}

No study reviewed has discussed long-term transport mobility outcomes for people who passed or failed evaluations.

\section{Will assessment prevent crashes or fatalities?}

No study has evaluated this question.

In the absence of RCTs of both potential benefits and negative consequences from driving assessment, it is reasonable to consider conducting prospective trials of assessment versus no assessment, but with an independent safety committee reviewing the outcomes regularly during the course of the trial. However a trial of no assessment will not be feasible in regions with legally mandated specialised assessments for people with dementia. Another approach, in regions without standardised assessment of drivers with dementia, may be a trial of standardised testing (by office or road test) versus usual care with outcomes of transport mobility, time to driving cessation, crash or adverse driving behaviour.

\section{What outcome measures might be used to measure transport mobility?}

Transport mobility is poorly studied as most research focuses on driver safety, and is hampered by lack of a concise definition or screening instrument, for example, someone may have good transport support and access to services while not driving (i.e. due to good family support), or may hold a license and insurance but may not feel that they have good transportation (through fear of rush hour traffic, difficulty with hospital parking lots). Conceptual models of transport mobility have been outlined by Rosenbloom 1993 and Metz 2000 in an attempt to operationalise aspects of mobility not captured in existing studies but as yet there is little consensus on appropriate measures of transport mobility. Spinney 2009 used data from the General Social Survey in Canada and showed a significant decline in transport mobility benefits in the domains of psychological benefits, exercise benefits, communityhelping and community-socialising with increasing age. This decline in transport mobility was associated with a significant decline in quality of life but driving was not specifically measured. A further, but not co-terminous, measure is driving cessation, which may stand as a useful rough measure, particularly in jurisdictions such as the US where public transport usage by older people is very low and does not increase after driving cessation (Giuliano 2003). Increasing interest is also focusing on multi-modality of transport in older populations, the demographic group within which dementia is most common (Satariano 2012)

\section{What outcome measures should be used to measure driver safety?}

\section{Crash rate?}

This is an area fraught with methodological pitfalls as demonstrated by Hakamies-Blomqvist 1998 and as such there is mixed evidence that drivers with mild cognitive impairment (MCI) and mild dementia will have an increased crash rate. Few authors have attempted a prospective study on crash rate. Anderson 2005 found a positive correlation between neuro-psychological tests (Rey Auditory Verbal Learning Test (AVLT) and Complex Figure Test Recall (CFTR)) with prospective crash rate. They also assessed participants on a driving simulation and a composite score from all the neuropsychological tests, which correlated with each other but not with prospective crash rate. Ott 2008 prospectively evaluated driving performance in participants with early Alzheimer's disease (AD) and healthy controls at six-month intervals. They found that the rate of motor vehicle accidents was not significantly different at baseline and that over the initial 18 months more crashes were observed in the control group but that after correction for miles driven this difference was not significant.

Crash rates have been suggested to be higher in retrospective studies; however, these studies are dependent on the accuracy of recalled information and results have differed considerably when data are collected from participants, carers or police records. Stutts 1998 looked at cognitive performance and found that although the association with retrospective, state-recorded crashes in older adults was present the effect was small (less than two-fold increase comparing the top and bottom deciles on cognitive scores) and they were not able to identify a cut-off point that identified a significantly higher risk of crash. Trobe 1996 and Carr 2000 suggested that there was no increased risk of crash in people with dementia who's Clinical Dementia Rating (CDR) (Morris 1994) score was between 0.5 and 1 when looking at state recorded crash rates rather than those recalled by subjects, carers or relatives. This may represent a difference in the types of crashes reported to local authorities and although we can reasonably infer that more serious crashes are more likely to be recorded and that retrospectively recalled events may be less accurate, we have no comparative data on these systems of reporting. Parker's paper has built on previous evidence to show that driving errors are not well correlated with future crashes but previous violations were (Parker 2000). This may go some way to explain the discrepancy between high failure rates on road tests and low reported accident rates. Retrospective odds ratios (OR) for crash comparing drivers with dementia and with no dementia have been reported from 7.9 by Friedland 1988 to 10.7 by Zuin 2002 . These studies show a marked difference 
with respect to numbers of subjects, which may help explain the variable strength of the associations (Trobe: $\mathrm{n}=858$, Carr: $\mathrm{n}=$ 121, Zuin: $\mathrm{n}=87$, Friedland: $\mathrm{n}=50$ ). A much larger study involving 3238 older drivers applying for re-licensing had cognitive tests (Trail Making tests A and B, American Association of Retired Persons Reaction Time test and Short Blessed Cognitive screen) compared with State crash records for the previous three years (Stutts 1998). In that time frame there were 411 crashes including 97 crashes by 45 people, an annual average of 0.043 crashes per person. The investigators found an OR of approximately 1.5 for crashes comparing drivers with cognitive performance in the lowest decile to those in the highest decile. Unfortunately this study did not document a history of dementia in any driver or use cognitive assessments that would allow a diagnosis of dementia, so extrapolating these data to drivers with dementia is difficult. We might infer that the lowest decile of cognitive performance group included at least some people with dementia but the magnitude of the effect on crash risk is unknown.

Despite the fact that it is a study of older drivers and does not diagnose or identify a diagnosis of dementia in any participant or group, the Maryland Prospective Older Driver Study (Staplin 2003) can be useful to demonstrate some of the difficulties encountered in driving research. In this paper, 2508 adults over 55 years of age were screened using cognitive and physical performance measures in Maryland. Subjects were recruited by random invitation from all licensed drivers, by medical referral and at relicensing at a senior citizens residential area. This had the advantages of a prospective follow-up for a mean of 20 months following assessment for crash and moving violation outcomes in a large population-based sample. They suggest, based on peak ORs for crash in each of four cognitive tests that cut-off points can be identified for increased risk of crash and high risk requiring intervention. ORs for crash at the following cut-points were: Motor-Free Visual Perception Test (Visual Closure subtest) (MVPT/VC): 5 incorrect, OR 4.96; Trail Making Test, Part B: $180 \mathrm{sec}$, OR 3.5; Cued/Delayed Recall: 2 incorrect, OR 2.92; Useful Field Of View subtest 2: $300 \mathrm{msec}$, OR 2.48. Using raw data in the paper we may extrapolate some values for sensitivity and specificity based on the strongest predictor, MVPT/VC, as a screening tool. MVPT/VC of 5 or more correctly predicted 18 crashes had 258 false positives, 93 false negatives and 1503 true negatives in the 1872 participants who had valid test results. This gives us a positive predictive value of $93 \%$, negative predictive value of $94 \%$ and a sensitivity and specificity of $83 \%$ and $85 \%$, respectively. If we look at the test as an intervention to prevent crashes, then we will need to screen 143 older drivers in order to prevent one crash in the following 20 months and an additional 20 drivers will fail testing.

\section{Driving test performance?}

There are reports that drivers with MCI and AD will have a high failure rate on driving tests from which we might infer a higher risk of crash; however, rates of driving test failure vary considerably and, with the exception of Anderson's paper quoted above (Anderson 2005), none of these estimates have been validated prospectively. Snellgrove 2000 reported the highest driving test failure rate in a non-peer reviewed paper for the Australian Transport Safety Bureau. However, this was a highly selected group (consecutive referrals to a memory clinic) with no control group but they did demonstrate an extremely high rate of failure on their road test: $70 \%$ of the group of 117 subjects with predominantly early dementia $(80 \%)$ and MCI (20\%). Of particular concern was their finding that $50 \%$ of the group required a physical intervention by the assessor to prevent a crash (a finding that has not been reported in any other paper). They also found that $50 \%$ of the MCI group failed the road test. Similarly, $41 \%$ of 55 participants with dementia were reported to fail the road test in Clark 2005 and 63\% of 19 subjects for Fox 1997, 36\% of 96 subjects with cognitive impairment in Kay 2009, 65\% of 99 subjects with dementia in Carr 2011 but only $18 \%$ of 65 drivers with dementia in Lincoln 2010. Comparative data versus controls were found in Duchek 2003, which gives test failure percentages of $30 \%$ versus $3 \%$ for people with and without dementia, and from Lincoln 2006, 37\% versus $0 \%$. Ott 2008 showed an increased hazard ratio for test failure of 3.51 in people with established dementia (CDR 1.0) versus early dementia (CDR 0.5) in a prospective study over 18 months. In addition, the CDR 1.0 group also showed a higher rate of driving cessation: only $31 \%$ of the CDR 1.0 presented for re-test at 18 months compared to $48 \%$ of CDR 0.5 . Road test failure rates in Berndt 2008 were $34 \%$ for CDR 0.5, 58\% for CDR 1.0 and $95 \%$ for CDR 2.0. Interestingly one person with CR 2.0 passed the road test suggesting that there may be some merit in offering a road test to people who wish to avail of the opportunity irrespective of their cognitive testing.

\section{Driving simulator performance?}

Simulators have also demonstrated higher rates of adverse driving behaviours in studies by Rebok 1994, Cox 1998, Frittelli 2009 and Vaux 2010 and also crashes (Rizzo 1997; Rizzo 2001; Uc 2006, Frittelli 2009). However, some authors believe that performance in driving simulators is not strongly related to on-road driving performance (Bylsma 1997; Rizzo 2001).

\section{Is there documented evidence of negative effects of assessment?}

The numbers of older people who would decline voluntary testing are significant. In the Maryland Programme of Older Driver Screening, 53\% of a sample of 3974 older drivers declined driver screening offered to them (Ball 2006). There was no difference in retrospective crash rate for those screened and those who declined and, unexpectedly, participants were more likely to be involved in prospective crashes. This sample was taken from older people 
presenting for re-licensing and participants were not assessed for the presence of dementia. Unfortunately there was no mention of comparative mobility and continued driving rates in the two groups. Snellgrove 2000 and Clark 2005 also reported on those who refused on-road testing: $36 \%$ to $54 \%$ of those who refused said that they would rather give up their license rather than retest. Both of these studies and also Stutts 1998 and Duchek 2003 indicate that these subjects do not differ from the experimental group in age, sex and Mini Mental State Examination (MMSE) score so we might infer that it reflects a population of people who may have normal driving skill who are negatively influenced by the assessment process with the attendant risks of depression, isolation and social exclusion suggested by Marottoli 1997, Marottoli 2000 and Ragland 2005 and also early entry into nursing homes (Freeman 2006). Data from both Meuser 2009 and Snyder 2009 show that the combination of the test failure rate and a lack of appeals or applications for re-testing meant that $90 \%$ to $96.5 \%$ of drivers reported as impaired did not resume driving. Unfortunately, neither study documented the effect on crashes or traffic violations or on the health of reported drivers.

Driver screening for cognitive impairment has also been shown to lack utility and is associated with increased traffic fatalities in a study that looked at the impact of a decision by the Danish government to add a brief cognitive status examination to medical screening of older drivers (Siren 2012). This is against a background of other studies that consistently support the hypothesis that mandatory medical testing of older drivers is not associated with reduced fatalities, and indeed that older drivers in the jurisdictions without testing had a significantly safer traffic record (Hakamies-Blomqvist 1996; Langford 2004).

\section{What assessment measures should be used?}

\section{Neuropsychology}

Although studies of older drivers without dementia have shown evidence that office-based tests correlate with future crashes, this has not been evaluated in drivers with a diagnosed dementia. What can be said is that in studies that included people with diagnosed dementia, office-based tests correlate, grossly and without helpful cut-off points, with road test performance and driving simulator performance. Also many studies have shown the strongest correlation between road testing requires a composite of multiple tests (Rizzo 1997; Anderson 2005; Clark 2005; Lincoln 2006), which may limit their use to trained individuals and require lengthy assessments. Clark's composite was more realistic (MMSE, Trail Making test-A and Wechsler Adult Intelligence Scale-block design) with a sensitivity and specificity of $82 \%$ and $90 \%$, respectively, but it remains to be established that such an assessment is independently adequate to disqualify drivers or merely a screening tool to identify those requiring road testing. There is little evidence that simple tests alone are as effective as road tests. Their most likely role is in screening to identify those in need of more detailed evaluation. Even with composite tests, such as the Stroke Driver Screening Assessment (SDSA) (Nouri 1992), adjustment has been needed for stroke in international populations (Lundberg 2003), and have needed to be used in other combinations of instruments for Parkinson's disease, traumatic brain injury (Radford 2004) and dementia (Lincoln 2006). The Nordic version of the SDSA has been shown to be effective in evaluating stroke drivers but had poor sensitivity and specificity in drivers with dementia (Selander 2010).

\section{Behaviour/driving specific}

The model of assessment suggested by Michon 1985 and operationalised by de Raedt 2000 uses a hierarchical and behavioural approach to the driving task. Michon's model of selection, optimisation and compensation describes successful adaptive strategies in individuals with disability. Examining driving behaviour in similar terms may help identify those able to overcome increasing levels of disability - physical or psychological. De Raedt's model examined driving behaviour in three hierarchies: strategic behaviours involved in planning destinations and routes and avoiding hazardous weather or traffic conditions; tactical refers to anticipatory behaviours such as speed adaptation; operational behaviour is the physical performance of the task (examined in most studies). De Raedt showed high levels of strategic behaviours in those performing badly on road tests but who did not have high accident rates. High accident rates were more associated with low tactical performance scores. This adds an extra dimension to assessment and may help explain the apparent discrepancy between high test failure rates and low per capita crash rates as well as some of the variability in the studies quoted. This model was used by Grace 2005 in a small study with 21 in each group comparing participants with AD, Parkinson's disease and healthy controls. In this study, test failure was rare: only two of the AD group and none of the other two groups failed the road test. However, errors were more common in AD and Parkinson's disease groups, with strategic, tactical and operational errors observed in people with $\mathrm{AD}$ while only tactical errors were observed in people with Parkinson's disease. This may suggest that a single standardised test will not be suitable in all older drivers or even all neurologically impaired drivers and a tailored approach may be necessary. Another approach that has more congruence with modern concepts of driver behaviour is that of self efficacy, and an early study in stroke (an illness with high levels of cognitive impairment) has shown promise (George 2007).

\section{On-road tests}

Many studies have used on-road testing as their gold standard (Hunt 1993; Fitten 1995; Fox 1997; Hunt 1997; Dobbs 1998; 
Snellgrove 2000; Duchek 2003; Wild 2003; Brown 2005; Clark 2005; Grace 2005; Ott 2005; Uc 2005; Lincoln 2006; Berndt 2008; Ott 2008; Dawson 2009; Kay 2009; Okonkwo 2009; Lafont 2010; Lincoln 2010; Patomella 2010; Selander 2010; Barrash 2010 Carr 2011). The road test lacks an accepted standard and considerable variation exists in term of vehicles, routes and tasks. More recent studies have begun using standardised and validated road tests such as the Sepulveda Road test (Fitten 1995), the Washington Road Test (Hunt 1997) or the Test-ride for Investigating Practical fitness to drive or TRIP (Tant 2002) designed specifically for older driver assessment. Prospective studies will be required to define cut-off scores that predict crash risk.

\section{Driving simulators}

Driving simulators have been used in many studies (Rebok 1994; Rizzo 1997; Cox 1998; Rizzo 2001; Anderson 2005; Uc 2006; Frittelli 2009; Vaux 2010). Simulators have obvious advantages, allowing detailed assessment in a safe and controlled environment; however, they have not been shown to predict prospective crashes and some authors feel they are not correlated well with the driving task in older drivers and drivers with dementia (Bylsma 1997; Rizzo 2001). There is also considerable variation in the technology involved ranging from computer-based simulations (Rebok 1994) to scale-model vehicles that simulate audiovisual data in addition to momentum (Rizzo 2001). Tolerability may also be problematic as simulators need to have verisimilitude but older people also get more motion sickness (Edwards 2003).

\section{Dementia type}

$\mathrm{AD}$ is specifically evaluated in most studies although many of the studies did not specify which dementia subtypes were within the experimental group or did not use consistent and clinically useful criteria (such as CDR or NINDS) to document disease severity. Vascular dementia $(\mathrm{VaD})$ is rarely tested and then usually as a part of an unselected dementia population. No subgroup analysis or specific studies of driving in $\mathrm{VaD}$ were identified. Fitten 1995, Zuin 2002, Clark 2005 and Lincoln 2010 were the only studies identified that specifically mentioned including a number of subjects with $\mathrm{VaD}$ but did not look at differential outcomes due to small numbers. Fronto-temporal dementia (FTD) has only been evaluated in one study (de Simone 2007), which showed a higher rate of crashes and errors in a simulated drive but only enrolled 15 subjects and 15 controls. Zuin 2002 did comment on a particularly high incidence of adverse driving behaviour in FTD but this only accounted for two out of 87 subjects and no further analysis was attempted. Lincoln 2010 also included a small number of people with VaD, FTD and dementia with Lewy bodies (DLB) but the numbers were too small to yield significant results. Other forms of dementia are almost never evaluated in studies despite reasonable suspicion of higher risk with deficits in perceptual skills and impaired judgement and disinhibition, for example, in DLB. It would seem logical to suggest that deficits of people with $\mathrm{VaD}$, FTD and DLB may not correlate well with the studies on people with $\mathrm{AD}$ and would need specific studies to validate driving assessment techniques.

\section{Dementia rating}

Use of clinically relevant instruments such as CDR to rate dementia severity have helped to categorise drivers who perform poorly in some studies (Hunt 1993; Duchek 2003; Ott 2008) and by incorporating functional and behavioural measures may have stronger predictive value. As discussed earlier, Ott 2008 showed a significant difference in prospective driving performance according to CDR score reinforcing the value of road testing in earlier stages of $\mathrm{AD}$ and in at least one case in a person with a CDR score of 2.

\section{Functional tests}

Functional measures, such as delayed recall, Trail Making test, visual perception, useful field of view, lower limb strength, and head and neck mobility, used in the Maryland Pilot Older Driver Study (Staplin 2003a), are potentially reliable predictors of crash risk with clear cut-off scores thus far only evaluated in an unselected older driver population. It bears mentioning though in that this is the first study that had a component looking at mobility and driving cessation. Newer data from the study, however, indicate that the predictive value of functional tests may decrease with increasing time since assessment, although the predictive value of delayed recall and rapid pace walk was preserved (Staplin 2003).

\section{Collateral history}

Collateral history is useful but may be misleading and subject to positive and negative bias. Wild 2003 showed more accurate prediction of driving ability from carers than people with $\mathrm{AD}$ but not for healthy older people. However, carers' assessment of functional impairments can be influenced by the burden placed on a carer's time (Zanetti 1999) and carers may have vested interests in a person's continued driving, in the example of a non-driving spouse. This may explain the higher crash rates estimated by carers as found in Friedland 1988. Despite this, dementia research in other fields lends credence to the collateral history, which can be a more accurate estimate of cognitive and functional decline (Archer 2007).

\section{Other approaches to managing driving and dementia: mandatory reporting and voluntary reporting}

A study from Oregon showed that, where physician reporting of impaired drivers was linked to mandatory suspension from driving, only $18.5 \%$ of 1664 drivers requested a re-test or appeal 
against suspension and that $56 \%$ of those re-tested regained driving privileges (Snyder 2009). The majority (88.8\%) of these automatic suspensions were for cognitive impairment. No data have been presented on whether this measure improves safety on Oregon's roads.

Meuser 2009 described a system where introduction of voluntary reporting of impaired drivers in Missouri led to driving cessation in $96.5 \%$ of 4100 reported individuals, $50 \%$ of whom did not seek any further assessment. This measure did lead to a reduction in crashes in this group but the study did not look at the impact on mortality or morbidity outcomes for this group other than motor vehicle accidents.

\section{Summary}

Our findings, therefore, continue to demonstrate a deficit in the transport literature for people with dementia. Despite considerable international variation in the regulatory and legislative processes for driving assessment in people with dementia there is no evidence from RCTs or prospective studies that driving assessment will help maintain mobility or improve safety for drivers with dementia. The subject of mobility outcomes after driving assessment has been overlooked thus far. Drawing on the literature for the larger numbers of older driver, little evidence has, so far, been forthcoming that there is any benefit in these driver screening programmes. Studies evaluating driving skills in people with dementia are fraught with methodological difficulties and are largely focused on rare outcomes such as crashes and therefore rely on surrogate markers such as cognitive tests, driving simulators and road tests. The overwhelming majority of these tests have not been evaluated prospectively in people with dementia and so can only offer speculative data on crash risk. Finally, given the evidence of negative effects of mandatory assessment and driving cessation more prospective data are required regarding positive and negative outcomes for people with dementia who undergo driving assessment.

\section{AUTHORS, CONCLUSIONS}

\section{Implications for practice}

There is no randomised evidence to indicate whether neuropsychological, on-road or other assessments of driving ability can help support safe drivers to remain mobile, or to reduce crashes.

\section{Implications for research}

More work is required to identify the optimal assessment strategy to help preserve transport mobility. A key challenge here is the development of a concise measure of transportation resources and quality, as suggested by Metz 2004.

Screening appears to discriminate unfairly against older drivers and yet in a population who appear to have declining driving skills there is understandable concern about crash risk. Further research is required to develop assessment tools that can reliably identify unsafe drivers with dementia in an office-based setting. Behavioural models may be of benefit here.

RCTs of driving assessment should involve a careful design, randomising people who drive to either formal testing or usual care and assessment, with longitudinal follow-up of satisfaction with transport (Rosenbloom 2003) and crashes or violations. Ethically, this may not pose a public health hazard in view of some memory clinic studies that suggest no increase in crashes in those with dementia (Drachman 1993; Trobe 1996; Carr 2000). Due care will need to be given to advice to participating drivers on informing driver licensing authorities and insurance companies, depending on the jurisdiction(s) within which the study is taking place. The study should also incorporate regular data review by an independent safety committee. As it is clearly undesirable that all drivers with dementia continue driving indefinitely, the use of a measure of transport efficacy, such as the Life Space Questionnaire (Stalvey 1999). may be a better guide to the primary question posed. It is likely that a close monitoring of the study for adverse events would be the best guide to the potential hazards, as, given that crashes are infrequent events, a study based purely on the secondary objective of safety would have to be very large. Extrapolating from Staplin 2003 where 111 out of 1876 participants in the License Renewal Sample crashed in the 20 month' follow-up, giving a crash rate of 0.06 per person over 20 months. Using JMP statistical software (SAS Institute) we estimate that a sample size of 5293 in each group would be required to have an $80 \%$ power to detect a $20 \%$ difference in crash rate between an unselected older driver population and a dementia group in the same time frame. If, however, we were to choose a larger estimate of increased crash risk such as a $50 \%$ difference in crash rates, our required sample size would be 953 per group. For the primary research objective of continued driving, cessation over a 23 -month period was almost $50 \%$ in a Canadian study of 200 drivers with dementia (Herrmann 2006), giving a withdrawal rate of 0.485 per person over a 23 -month period. This would give us a sample size of 2625 in each group to have an $80 \%$ power to detect a $10 \%$ difference in driving cessation.

\section{ACKNOWLEDGEMENTS}

The authors wish to thank the consumer editor, Aisling Lynch.

Driving assessment for maintaining mobility and safety in drivers with dementia (Review) 


\section{R E F E R E N C E S}

\section{References to studies excluded from this review}

Adler 2008 \{published data only\}

Adler G, Silverstein NM. At-risk drivers with Alzheimer's disease: recognition, response, and referral. Traffic Injury Prevention 2008;9(4):299-303.

Akinwuntan 2007 \{published data only\}

Akinwuntan AE, Devos H, Feys H, Verheyden G, Baten G, Kiekens C, et al.Confirmation of the accuracy of a short battery to predict fitness-to-drive of stroke survivors without severe deficits. Journal of Rehabilitation Medicine 2007;39 (9):698-702.

Anderson 2005 \{published data only\}

Anderson SW, Rizzo M, Shi Q, Uc EY, Dawson JD. Cognitive Abilities Related to Driving Performance in a Simulator and Crashing on the Road. Proceedings of the Third International Driving Symposium on Human Factors in Driver Assessment, Training and Vehicle Design; 2005 Jun 27-30; Rockport (ME). 2005.

Anstey 2009 \{published data only\} Anstey KJ, Wood J, Caldwell H, Kerr G, Lord SR. Comparison of self-reported crashes, state crash records and an on-road driving assessment in a population-based sample of drivers aged 69-95 years. Traffic Injury Prevention 2009; 10(1):84-90.

ANZSGM 2010 \{published data only\}

Australian and New Zealand Society for Geriatric Medicine. Australian and New Zealand Society for Geriatric Medicine position statement driving and dementia. Australas Journal of Ageing 2010;29(3):137-41.

Arai 2009 \{published data only\}

Arai Y, Arai A, Misuno Y. Automobile driving by dementia patients: a need for social support. Seishin Shinkeigaku Zasshi 2009;111(1):101-7.

Badenes 2007 \{published data only\} Badenes Guia D, Casas Hernanz L, Aguilar Barbera M, Cejudo Bolivar JC. Assessment of dementia of car driving abilities in patients with mild cognitive impairment and dementia. Mapfre Medicina 2007;18(2):98-107. [MEDLINE: ISSN: 1130-5665]

Badenes-Guia 2008 \{published data only\} Badenes Guia D, Casas Hernanz L, Cejudo Bolivar JC, Aguilar Barberà M. Evaluation of the capacity to drive in patients diagnosed of mild cognitive impairment and dementia. Neurologia 2008;23(9):575-82.

Ball 2006 \{published data only\}

Ball KK, Roenker DL, Wadley VG, Edwards JD, Roth DL, McGwin G, Jr, et al.Can high-risk older drivers be identified through performance-based measures in a Department of Motor Vehicles setting?. Journal of the American Geriatrics Society 2006;54(1):77-84.

Barrash 2010 \{published data only\} Barrash J, Stillman A, Anderson SW, Uc EY, Dawson JD, Rizzo M. Prediction of driving ability with neuropsychological tests: demographic adjustments diminish accuracy. Journal of the International Neuropsychological Society 2010;16(4):679-86.

Berndt 2008 \{published data only\}

Berndt A, Clark M, May E. Dementia severity and on-road assessment: briefly revisited. Australas Journal on Ageing 2008;27(3):157-60.

Breen 2007 \{published data only\} Breen DA, Breen DP, Moore J W, Breen P A, O'Neill D. Driving and dementia. BMJ 2007;334(7608):1365-9.

Brown 2005 \{published data only\} Brown LB, Ott BR, Papadonatos GD, Sui Y, Ready RE, Morris JC. Prediction of on-road driving performance in patients with early Alzheimer's disease. Journal of the American Geriatrics Society 2005;53:94-8.

Bylsma 1990 \{published data only\} Bylsma FW, Rebok GW, Keyl PM. The effects of Alzheimer's disease on driving related abilities. Neurobiology of Aging 1990;11(3):348.

Bylsma 1997 \{published data only\} Bylsma FW. Simulators for assessing driving skills in demented patients. Alzheimer's Disease and Associated Disorders 1997;11 Suppl 1:17-20.

Carr 2000 \{published data only\} Carr DB, Duchek J, Morris JC. Characteristics of motor vehicle crashes of drivers with dementia of the Alzheimer type. Journal of the American Geriatrics Society 2000;48(1): $18-22$.

Carr 2011 \{published data only\} Carr DB, Barco PP, Wallendorf MJ, Snellgrove CA, Ott BR. Predicting road test performance in drivers with dementia. Journal of the American Geriatrics Society 2011;59(11): 2112-7.

Clark 2005 \{published data only\} Clark M, Hecker J, Cleland E, Field C, Berndt A, Crotty M, Snellgrove C. Dementia and Driving. Australian Transport Safety Bureau. CANBERRA ACT 2608, Australia, 2005.

Cooper 1993 \{published data only\} Cooper PJ, Tallman K, Tuokko H, Beattie BL. Vehicle crash involvement and cognitive deficit in older drivers. Journal of Safety Research 1993;24:9-17.

Cotrell 1999 \{published data only\} Cotrell V, Wild K. Longitudinal study of self-imposed driving restrictions and deficit awareness in patients with Alzheimers disease. Alzheimer Disease and Associated Disorders 1999;13(3):151-6.

Cox 1998 \{published data only\} Cox DJ, Quillian WC, Thorndike FP, Kovatchev BP, Hanna $B$. Evaluating driving performance of outpatients with Alzheimer disease. Journal of the American Board of Family Practice 1998;11(4):264-71. 
Cushman 1992 \{published data only\}

Cushman LA. The Impact of Cognitive Decline and Dementia on Driving in Older Adults. AAA Foundation for Traffic Safety. Washington DC: AAA Foundation for Traffic Safety, 1730 M Street, NW Suite 401 Washington DC, 20036, 1992.

Daiello 2010 \{published data only\} Daiello LA, Ott BR, Festa EK, Friedman M, Miller LA, Heindel WC. Effects of cholinesterase inhibitors on visual attention in drivers with Alzheimer disease. Journal of Clinical Psychopharmacology 2010;30(3):245-51.

Dawson 2009 \{published data only\} Dawson JD, Anderson SW, Uc EY, Dastrup E, Rizzo M. Predictors of driving safety in early Alzheimer disease. Neurology 2009;72(6):521-7.

de Simone 2007 \{published data only\} de Simone V, Kaplan L, Patronas N, Wassermann EM, Grafman J. Driving abilities in frontotemporal dementia patients. Dementia and Geriatric Cognitive Disorders 2007; 23(1):1-7.

Devos 2007 \{published data only\}

Devos H, Vandenberghe W, Nieuwboer A, Tant M, Baten G, De Weerdt W. Predictors of fitness to drive in people with Parkinsons disease. Neurology 2007;69(14):1434-41.

\section{Dobbs 1997 \{published data only\}}

Dobbs AR. Evaluating the driving competence of dementia patients. Alzheimer Disease and Associated Disorders 1997;11 Suppl 1:8-12.

Drachman 1993 \{published data only\} Drachman DA, Swearer JM. Driving and Alzheimer's disease: the risk of crashes. Neurology 1993;43(12): 2448-56.

Dubinsky 1992 \{published data only\} Dubinsky RM, Williamson A, Gray CS, Glatt SL. Driving in Alzheimer's disease. Journal of the American Geriatrics Society 1992;40(11):1112-16.

Duchek 2003 \{published data only\}

Duchek JM, Carr DB, Hunt L, Roe CM, Xiong C, Shah $\mathrm{K}$, et al.Longitudinal driving performance in early-stage dementia of the Alzheimer type. Journal of the American Geriatrics Society 2003;51(10):1342-7.

Ernst 2010 \{published data only\} Ernst J, Krapp S, Schuster T, Förstl H, Kurz A, DiehlSchmid J. Car driving ability of patients with frontotemporal lobar degeneration and Alzheimer's disease. Nervenarzt 2010;81(1):79-85.

Fitten 1995 \{published data only\} Fitten LJ, Perryman KM, Wilkinson CJ, Little RJ, Burns MM, Pachana N, et al.Alzheimer and vascular dementias and driving. A prospective road and laboratory study. JAMA 1995;273:1360-5.

Fox 1997 \{published data only\} Fox GK, Bowden SC, Bashford GM, Smith DS. Alzheimer's disease and driving: prediction and assessment of driving performance. Journal of the American Geriatrics Society 1997;45:949-53.

Friedland 1988 \{published data only\} Friedland RP, Koss E, Kumar A, Gaine S, Metzler D, Haxby $\mathrm{JV}$, et al.Motor vehicle crashes in dementia of the Alzheimer type. Annals of Neurology 1988;24:782-6.

Frittelli 2009 \{published data only\} Frittelli C, Borghetti D, Iudice G, Bonanni E, Maestri $\mathrm{M}$, Tognoni $\mathrm{G}$, et al.Effects of Alzheimer's disease and mild cognitive impairment on driving ability: a controlled clinical study by simulated driving test. International Journal of Geriatric Psychiatry 2009;24(3):232-8.

Gilley 1991 \{published data only\}

Gilley DW, Wilson RS, Bennett DA, Stebbins GT, Bernard $\mathrm{BA}$, Whalen ME, et al.Cessation of driving and unsafe motor vehicle operation by dementia patients. Archives of Internal Medicine 1991;151(5):941-6.

Grace 2005 \{published data only\} Grace J, Amick MM, D'Abreu A, Festa EK, Heindel WC, Ott BR. Neuropsychological deficits associated with driving performance in Parkinson's and Alzheimer's disease. Journal of the International Neuropsychological Society 2005;11(6): 766-75.

Hunt 1993 \{published data only\} Hunt L, Morris JC, Edwards D, Wilson BS. Driving performance in persons with mild senile dementia of the Alzheimer type. Journal of the American Geriatrics Society 1993;41:747-52.

Hunt 1997 \{published data only\} Hunt LA, Murphy CF, Carr D, Duchek JM, Buckles V, Morris JC. Reliability of the Washington University Road Test. A performance-based assessment for drivers with dementia of the Alzheimer type. Archives of Neurology 1997; 54:707-12.

Hunt 2010 \{published data only\}

Hunt LA, Brown AE, Gilman IP. Drivers with dementia and outcomes of becoming lost while driving. American Journal of Occupational Therapy 2010;64(2):225-32.

Innes 2005 \{published data only\}

Innes CR, Jones RD, Dalrymple-Alford JC, Hayes S, Hollobon S, Severinsen J, et al.Sensory-motor and cognitive tests predict driving ability of persons with brain disorders. Journal of Neurological Science 2007;260(1-2):188-98. * Innes CRH, Jones R, Anderson T, Dalrymple-Alford J, Hayes S, Hollobon S, et al.Prediction of driving ability in persons with brain disorders using sensory-motor and cognitive tests. Conference Proceedings of the Annual International Conference of the IEEE Engineering in Medicine and Biology Society. 2005; Vol. 5, issue 1: 5439-5442.

Iverson 2010 \{published data only\} Iverson DJ, Gronseth GS, Reger MA, Classen S, Dubinsky RM, Rizzo M, Quality Standards Subcommittee of the American Academy of Neurology. Practice parameter update: evaluation and management of driving risk in dementia. Neurology 2010;74(16):1316-24. 
Johansson 1997 \{published data only\}

Johansson K, Lundberg C. The 1994 International Consensus Conference on Dementia and Driving: a brief report. Alzheimer Disease and Associated Disorders 1997;11: $62-9$.

Kamimura 2009 \{published data only\}

Kamimura N. Dementia and automobile driving. Seishin Shinkeigaku Zasshi. 2009;111(8):960-6.

Kawano 2009 \{published data only\} Kawano N, Makino T, Suzuki Y, Umegaki H. Impact of driving cessation on daily transportation utility in elderly people with cognitive decline: a survey of patients in the memory clinic of an urban university hospital. Nihon Ronen Igakkai Zasshi 2009;46(5):420-7.

Kay 2009 \{published data only\}

Kay LG, Bundy AC, Clemson LM. Predicting fitness to drive in people with cognitive impairments by using DriveSafe and DriveAware. Archives of Physical Medicine and Rehabilitation 2009;90(9):1514-22.

Lafont 2010 \{published data only\}

Lafont S, Marin-Lamellet C, Paire-Ficout L, ThomasAnterion C, Laurent B, Fabrigoule C. The Wechsler Digit Symbol Substitution Test as the best indicator of the risk of impaired driving in Alzheimer disease and normal aging. Dementia and Geriatric Cognitive Disorders 2010;29(2): 154-63.

Laks 1999 \{published data only\}

Laks J, Marinho VM, Rozenthal M, Engelhardt E. Driving, cognitive impairment, and dementia [Direçäo, comprometimento cognitivo e dem?]. Revista Brasiliera de Neurologia 1999;35(5):131-5.

Laks 2000 \{published data only\}

Laks J, Munk M, Pessanha MR, Pinto SP, Engelhardt E. Elderly and driving: evaluation in a nursing home [Idosos com habilitaçäo para dirigir veículos automotores: avaliaçäo em um lar abrigado]. Jornal Brasiliero de Psiquiatria 2000; 49(10):399-404. [: ISSN: 0047-2085.]

Leproust 2008 \{published data only\}

Leproust S, Lagarde E, Salmi LR. Risks and advantages of detecting individuals unfit to drive: a Markov decision analysis. Journal of General Internal Medicine 2008;23(11): 1796-803.

Lincoln 2006 \{published data only\} Lincoln NB, Radford KA, Lee E, Reay AC. The assessment of fitness to drive in people with dementia. International Journal of Geriatric Psychiatry 2006;21(11):1044-51.

Lincoln 2010 \{published data only\}

Lincoln NB, Taylor JL, Vella K, Bouman WP, Radford KA. A prospective study of cognitive tests to predict performance on a standardised road test in people with dementia. International Journal of Geriatric Psychiatry 2010;25(5): 489-96.

Love 2007 \{published data only\}

Love CM. Cognitive impairment and dangerous driving: a decision-making model for the psychologist to balance confidentiality with safety. Dissertation Abstracts International: Section B: The Sciences and Engineering 2007; 68(3-B):1933. [: ISSN: 0419-4217.]

Lucas-Blaustein 1988 \{published data only\}

Lucas-Blaustein MJ, Filipp L, Dungan C, Tune L. Driving in patients with dementia. Journal of the American Geriatrics Society 1988;36(12):1087-91.

Lukas 2009 \{published data only\} Lukas A, Nikolaus T. Driving ability and dementia. Zeitschrift für Gerontologie und Geriatrie 2009;42(3): 205-11.

Man-Son-Hing 2007 \{published data only\} Man-Son-Hing M, Marshall SC, Molnar FJ, Wilson KG. Systematic review of driving risk and the efficacy of compensatory strategies in persons with dementia. Journal of the American Geriatrics Society 2007;55(6):878-84. [: ISSN:0002-8614]

Meuser 2006 \{published data only\}

Meuser TM, Carr DB, Berg-Weger M, Niewoehner P, Morris JC. Driving and dementia in older adults: implementation and evaluation of a continuing education project. Gerontologist 2006;46(5):680-7.

\section{Meuser 2009 \{published data only\}}

Meuser TM, Carr DB, Ulfarsson GF. Motor-vehicle crash history and licensing outcomes for older drivers reported as medically impaired in Missouri. Accident; Analysis and Prevention 2009;41(2):246-52.

Molnar 2006 \{published data only\}

Molnar FJ, Patel A, Marshall SC, Man-Son-Hing M, Wilson KG. Clinical utility of office-based cognitive predictors of fitness to drive in persons with dementia: a systematic review. Journal of the American Geriatrics Society 2006;54 (12):1809-24.

\section{Molnar 2007 \{published data only\}}

Molnar FJ, Marshall SC, Man-Son-Hing M, Wilson KG, Byszewski AM, Stiell I. Acceptability and concurrent validity of measures to predict older driver involvement in motor vehicle crashes: An Emergency Department pilot case-control study. Accident; Analysis and Prevention 2007; 39(5):1056-63.

Mosimann 2011 \{published data only\} Mosimann UP, Bächli-Biétry J, Boll J, Bopp-Kistler I, Donati F, Kressig RW, et al.Consensus recommendations for the assessment of fitness to drive in cognitively impaired patients. Praxis 2011;101(7):437.

Neitch 2011 \{published data only\}

Neitch SM, Madero G, Maynard S. Driving assessment results in patients with a diagnosis of Dementia. West Virginia Medical Journal 2011;107(3):54-8.

O'Connor 2010 \{published data only\} O'Connor ML, Edwards JD, Wadley VG, Crowe M. Changes in mobility among older adults with psychometrically defined mild cognitive impairment. Journals of Gerontology. Series B, Psychological Sciences and Social Sciences 2010;65B(3):306-16. 
Odenheimer 1994 \{published data only\}

Odenheimer GJ, Beaudet M, Jette AM, Albert MS, Grande L, Minaker KL. Performance-based evaluation of the elderly driver: safety, reliability and validity. Journal of Gerontology 1994;49(4):153-9.

Okonkwo 2009 \{published data only\}

Okonkwo OC, Griffith HR, Vance DE, Marson DC, Ball KK, Wadley VG. Awareness of functional difficulties in mild cognitive impairment: a multidomain assessment approach. Journal of the American Geriatric Society 2009;57 (6):978-84.

Oswanski 2007 \{published data only\}

Oswanski MF, Sharma OP, Raj SS, Vassar LA, Woods KL, Sargent WM, et al.Evaluation of two assessment tools in predicting driving ability of senior drivers. American Journal of Physical Medicine and Rehabilitation 2007;86(3):190-9.

Ott 2005 \{published data only\}

Ott B, Anthony D, Papandonatos GD, D’Abreu A, Burock J, Curtin A, et al.Clinician assessment of the driving competence of patients with dementia. Journal of the American Geriatrics Society 2005;53:829-33.

Ott 2008 \{published data only\}

Ott BR, Heindel WC, Papandonatos GD, Festa EK, Davis JD, Daiello LA, Morris JC. A longitudinal study of drivers with Alzheimers disease. Neurology 2008;70(14):1171-8.

Parker 2000 \{published data only\}

Parker D, McDonald L, Rabbitt P, Sutcliffe P. Elderly drivers and their accidents: the Aging Driver Questionnaire. Accident; Analysis and Prevention 2000;32(6):751-9.

Patomella 2010 \{published data only\}

Patomella AH, Tham K, Johansson K, Kottorp A. Pdrive on-road: internal scale validity and reliability of an assessment of on-road driving performance in people with neurological disorders. Scandinavian Journal of Occupational Therapy 2010;17(1):86-93.

Rapoport 2007 \{published data only\}

Rapoport MJ, Herrmann N, Molnar FJ, Man-Son-Hing M, Marshall SC, Shulman K, et al.Sharing the responsibility for assessing the risk of the driver with dementia. CMAJ 2007; 177(6):599-601.

Rebok 1994 \{published data only\} Rebok GW, Keyl PM. The effects of Alzheimer disease on driving-related abilities. Alzheimer Disease and Associated Disorders 1994;8(4):228-40.

Reger 2004 \{published data only\}

Reger MA, Welsh RK, Watson GS, Cholerton B, Baker LD, Craft S. The relationship between neuropsychological functioning and driving ability in dementia: a metaanalysis. Neuropsychology 2004;18(1):85-93.

Regtuijt 2007 \{published data only\}

Regtuijt EM, Kleinsman ACM, Slaets JPJ. Questioning the ability to drive in patients with cognitive disorders [Dutch]. Nederlands Tijdschrift Voor Geneeskunde 2007;151(36): 1965-9. [: ISSN:0028-2162]
Rizzo 1997 \{published data only\}

Rizzo M, Reinach S, McGehee D, Dawson J. Simulated car crashes and crash predictors in drivers with Alzheimer's disease. Archives of Neurology 1997;54:545-53.

Rizzo 2001 \{published data only\} Rizzo M, McGehee DV, Dawson JD, Anderson SN. Simulated car crashes at intersections in drivers with Alzheimer disease. Alzheimer Disease and Associated Disorders 2001;15(1):10-20.

Ross 2009 \{published data only\} Ross LA, Anstey KJ, Kiely KM, Windsor TD, Byles JE, Luszcz MA, Mitchell P. Older drivers in Australia: trends in driving status and cognitive and visual impairment. Journal of the American Geriatric Society 2009;57(10):1868-73.

Silva 2009 \{published data only\} Silva MT, Laks J, Engelhardt E. Neuropsychological tests and driving in dementia. Revista da Associação Médica Brasileira 2009;55(4):484-8.

Singh 2007 \{published data only\} Singh R, Pentland B, Hunter J, Provan F. Parkinson's disease and driving ability. Journal of Neurology, Neurosurgery and Psychiatry 2007;78(4):363-6. [: ISSN: 0022-3050]

Snellgrove 2000 \{published data only\} Snellgrove CA. Cognitive screening for the safe driving competence of older people with mild cognitive impairment or early dementia, 2000. www.infrastructure.gov.au/roads/ safety/publications/2005/pdf/cog_screen_old.pdf (accessed 2 April 2013).

Snyder 2009 \{published data only\} Snyder KM, Ganzini L. Outcomes of Oregon's law mandating physician reporting of impaired drivers. Journal of Geriatric Psychiatry and Neurology 2009;22(3):161-5.

Soderstrom 2009 \{published data only\} Soderstrom CA, Scottino MA, Joyce JJ, Burch C, Ho SM, Kerns TJ. Police referral of drivers to the Maryland Motor Vehicle Administration's Medical Advisory Board. Annals of Advances in Automotive Medicine 2009;53:105-16.

Staplin 2003 \{published data only\} Staplin L, Gish KW, Wagner EK. MaryPODS revisited: updated crash analysis and implications for screening program implementation. Journal of Safety Research 2003; 34(4):389-97.

Staplin 2003a \{published data only\} Staplin L, Lococo KH, Gish KW, Decina LE. Model driver screening and evaluation program final technical report: Vol. 2. Maryland Pilot Older Driver Study. www.nhtsa.gov/people/injury/olddrive/modeldriver/ volume_ii.htm (accessed 2 April 2013).

Stutts 1998 \{published data only\} Stutts JC, Stewart JR, Martell C. Cognitive test performance and crash risk in an older driver population. Accident; Analysis and Prevention 1998;30(3):337-46.

Szlyk 2002 \{published data only\} Szlyk JP, Myers L, Zhang Y, Wetzel L, Shapiro R. Development and assessment of a neuropsychological 
battery to aid in predicting driving performance. Journal of Rehabilitation Research and Development 2002;39(4): 483-96.

Taylor 2001 \{published data only\}

Taylor BD, Tripodes $\mathrm{S}$. The effects of driving cessation on the elderly with dementia and their caregivers. Accident; Analysis and Prevention 2001;33(4):519-28.

Trilling 2001 \{published data only\}

Trilling JS. Selections from current literature assessment of older drivers. Family Practice 2001;18(3):339-42.

Trobe 1996 \{published data only\}

Trobe JD, Waller PF, Cook-Flanagan CA, Teshima SM, Bieliauskas LA. Crashes and violations among drivers with Alzheimer disease. Archives of Neurology 1996;53(5):411-6.

Tuokko 1995 \{published data only\} Tuokko H, Tallman K, Beattie BL, Cooper P, Weir J. An examination of driving records in a dementia clinic. Journals of Gerontology. Series B, Psychological Sciences and Social Sciences 1995;50(3):S173-81.

Uc 2005 \{published data only\}

Uc EY, Rizzo M, Anderson SW, Shi Q, Dawson JD. Driver landmark and traffic sign identification in early Alzheimer's disease. Journal of Neurology, Neurosurgery and Psychiatry 2005;76:764-8.

Uc 2006 \{published data only\}

Uc EY, Rizzo M, Anderson SW, Shi Q, Dawson JD. Unsafe rear-end collision avoidance in Alzheimer's disease. Journal of the Neurological Sciences 2006;251(1-2):35-43.

Uc 2008 \{published data only\}

Uc EY, Rizzo M. Driving and neurodegenerative diseases. Current Neurology and Neuroscience Reports 2008;8(5): $377-83$.

Vaux 2010 \{published data only\}

Vaux LM, Ni R, Rizzo M, Uc EY, Andersen GJ. Detection of imminent collisions by drivers with Alzheimer's disease and Parkinson's disease: a preliminary study. Accident; Analysis and Prevention 2010;42(3):852-8.

Wadley 2009 \{published data only\}

Wadley VG, Okonkwo O, Crowe M, Vance DE, Elgin JM, Ball KK, et al.Mild cognitive impairment and everyday function: an investigation of driving performance. Journal of Geriatric Psychiatry and Neurology 2009;22(2):87-94.

Wild 2003 \{published data only\}

Wild $\mathrm{K}$, Cotrell V. Identifying driving impairment in Alzheimer disease: a comparison of self and observer reports versus driving evaluation. Alzheimer Disease and Associated Disorders 2003;17:27-34.

Withaar 2000 \{published data only\}

Withaar FK, Brouwer WH, van Zomeren AH. Fitness to drive in older drivers with cognitive impairment. Journal of the International Neuropsychological Society 2000;6(4): 480-90.

\section{Woolf 2006 \{published data only\}}

Woolf C, Heng K, Pan S, Layde MP, Zhu S. The elderly and motor vehicle crashes. Chinese Journal of Emergency Medicine 2006;15(1):6-12. [: ISSN: 1671-0282]

Zuin 2002 \{published data only\}

Zuin D, Ortiz H, Boromei D, Lopez OL. Motor vehicle crashes and abnormal driving behaviours in patients with dementia in Mendoza, Argentina. European Journal of Neurology 2002;9(1):29-34.

\section{Additional references}

\section{Archer 2007}

Archer HA, McFarlane F, Frost C, Cutler D, Fox NC, Rossor MN. Symptoms of memory loss as predictors of cognitive impairment: the use and reliability of memory ratings in a clinic population. Alzheimer Disease and Associated Disorders 2007;21(2):101-6.

\section{de Raedt 2000}

De Raedt R, Ponjaert-Kristoffersen I. Can strategic and tactical compensation reduce crash risk in older drivers?. Age and Ageing 2000;29(6):517-21.

\section{Dobbs 1998}

Dobbs AR, Heller RB. A comparative approach to identify unsafe older drivers. Accident; Analysis and Prevention 1998; 30(3):363-70.

\section{Edwards 2003}

Edwards CJ, Creaser JI, Caird JK, Lamsdale AM, Chisholm SL. Older and younger driver performance at complex intersections: implications for using perception-response time and driving simulation. Proceedings of the Second International Driving Symposium on Human Factors in Driver Assessment, Training, and Vehicle Design, Park City, Utah. 2003:7-12.

\section{Freeman 2006}

Freeman EE, Gange SJ, Munoz B, West SK. Driving status and risk of entry into long-term care in older adults. American Journal of Public Health 2006;96(7):1254-9.

\section{Fuller 2005}

Fuller R. Towards a general theory of driver behaviour. Accident; Analysis and Prevention 2005;37(3):461-72.

\section{George 2007}

George S, Clark M, Crotty M. Development of the Adelaide driving self-efficacy scale. Clinical Rehabilitation 2007;21 (1):56-61.

Giuliano 2003 Giuliano G, Hu H, Lee K. Travel Patterns in the Elderly: the Role of Land Usage. Los Angeles, CA: METRANS Transportation Center, 2003. [: METRANS project 00-8]

\section{Hakamies-Blomqvist 1996}

Hakamies-Blomqvist L, Johansson K, Lundberg C. Medical screening of older drivers as a traffic safety measure - a comparative Finnish-Swedish evaluation study. Journal of the American Geriatrics Society 1996;44(6):650-3. 


\section{Hakamies-Blomqvist 1998}

Hakamies-Blomqvist L. Older drivers' accident risk: conceptual and methodological issues. Accident; Analysis and Prevention 1998;30(3):293-7.

\section{Herrmann 2006}

Herrmann N, Rapoport MJ, Sambrook R, Hébert R, McCracken P, Robillard A. Predictors of driving cessation in mild-to-moderate dementia. CMAJ 2006;175(6):591-5.

\section{Langford 2004}

Langford J, Fitzharris M, Newstead S, Koppel S. Some consequences of different older driver licensing procedures in Australia. Accident; Analysis and Prevention 2004;36(6): 993-1001.

Lundberg 2003

Lundberg C, Caneman G, Samuelsson SM, HakamiesBlomqvist L, Almkvist $\mathrm{O}$. The assessment of fitness to drive after a stroke: the Nordic Stroke Driver Screening Assessment. Scandinavian Journal of Psychology 2003;44(1): 23-30.

\section{Marottoli 1997}

Marottoli RA, Mendes de Leon CF, Glass TA, Williams CS, Cooney LM Jr, Berkman LF, et al.Driving cessation and increased depressive symptoms: prospective evidence from the New Haven EPESE. Established Populations for Epidemiologic Studies of the Elderly. Journal of the American Geriatrics Society 1997;45(2):202-6.

\section{Marottoli 2000}

Marottoli RA, de Leon CFM, Glass TA, Williams CS, Cooney LM Jr, Berkman LF. Consequences of driving cessation: decreased out-of-home activity levels. Journals of Gerontology: Series B, Psychological Sciences and Social Sciences 2000;55(6):S334-40.

Martin 2005

Martin A, Balding L, O'Neill D. Are the media running elderly drivers off the road?. BMJ 2005;330:368.

\section{Metz 2000}

Metz DH. Mobility of older people and their quality of life. Transport Policy 2000;7(2):149-52.

\section{Metz 2004}

Metz D. Human mobility and transport policy. Ingenia 2004;18:37-42.

\section{Michon 1985}

Michon JA. A critical review of driver behaviour models: what do we know, what should we do?. In: Evans L, Schwing RC editor(s). Human Behaviour and Traffic Safety. New York: Plenum, 1985:487-525.

\section{Morris 1994}

Morris JC. The Clinical Dementia Rating (CDR). Current version and scoring rules. Neurology 1994;44:1983-4.

\section{Nouri 1992}

Nouri FM, Lincoln NB. Validation of a cognitive assessment: predicting driving performance after stroke. Clinical Rehabilitation 1992;6:275-81.

\section{Radford 2004}

Radford KA, Lincoln NB, Murray-Leslie C. Validation of the stroke drivers screening assessment for people with traumatic brain injury. Brain Injury 2004;18(8):775-86.

Ragland 2005

Ragland DR, Satariano WA, MacLeod KE. Driving cessation and increased depressive symptoms. Journals of Gerontology: Series A, Biological Sciences and Medical Science 2005;60A:399-403.

Ranney 1994

Ranney TA. Models of driving behavior: a review of their evolution. Accident; Analysis and Prevention 1994;26(6): 733-50.

\section{RevMan 2011}

The Nordic Cochrane Centre, The Cochrane Collaboration. Review Manager (RevMan). 5.. Copenhagen: The Nordic Cochrane Centre, The Cochrane Collaboration, 2011.

\section{Robinson 2004}

Robinson D, O'Neill D. Ethics of driving assessment in dementia care, competence and communication. In: Rai GS editor(s). Medical Ethics and the Elderly. Oxford: Radcliffe Publications, 2004:103-12.

\section{Rosenbloom 1993}

Rosenbloom S. Transportation needs of the elderly population. Clinics in Geriatric Medicine 1993;9(2): 297-310.

\section{Rosenbloom 2003}

Rosenbloom S, Ståhl A. Automobility among the elderly; the convergence of environmental, safety, mobility and community design issues. European Journal of Transport and Infrastructure Research 2003;2(3-4):197-214.

\section{Satariano 2012}

Satariano WA, Guralnik JM, Jackson RJ, Marottoli RA, Phelan EA, Prohaska TR. Mobility and aging: new directions for public health action. American Journal of Public Health 2012;102(8):1508-15.

\section{Selander 2010}

Selander H, Johansson K, Lundberg C, Falkmer T. The Nordic stroke driver screening assessment as predictor for the outcome of an on-road test. Scandinavian Journal of Occupational Therapy 2010;17(1):10-7.

\section{Siren 2012}

Siren A, Meng A. Cognitive screening of older drivers does not produce safety benefits. Accident; Analysis and Prevention 2012;45:634-8.

\section{Spinney 2009}

Spinney JEL, Scott DM, Newbold KB. Transport mobility benefits and quality of life: a time-use perspective of elderly Canadians. Transport Policy 2009;16(1):1-11.

\section{Stalvey 1999}

Stalvey BT, Owsley C, Sloane ME, Ball K. The Life Space Questionnaire: a measure of the extent of mobility of older adults. Journal of Applied Gerontology 1999;18:460. 


\section{Stutts 2003}

Stutts JC, Wilkins JW. On-road driving evaluations: a potential tool for helping older adults drive safely longer. Safety Research 2003;34(4):431-9.

Tant 2002

Tant MLM, Brouwer WH, Cornelissen FW, Kooijman AC. Driving and visuospatial performance in people with hemianopia. Neuropsychological Rehabilitation 2002;5: 419-37.

Vernon 2002

Vernon DD, Diller EM, Cook LJ, Reading JC, Suruda
AJ, Dean JM. Evaluating the crash and citation rates of Utah drivers licensed with medical conditions, 1992-1996. Accident; Analysis and Prevention 2002;34(2):237-46.

\section{Zanetti 1999}

Zanetti O, Geroldi C, Frisoni GB, Bianchetti A, Trabucchi $\mathrm{M}$. Contrasting results between caregiver's report and direct assessment of activities of daily living in patients affected by mild and very mild dementia: the contribution of the caregiver's personal characteristics. Journal of the American Geriatrics Society 1999;47(2):196-202.

* Indicates the major publication for the study 


\section{CHARACTERISTICS OF STUDIES}

\section{Characteristics of excluded studies [ordered by study ID]}

\begin{tabular}{|c|c|}
\hline Study & Reason for exclusion \\
\hline Adler 2008 & $\begin{array}{l}\text { Non-RCT } \\
\text { Review article }\end{array}$ \\
\hline Akinwuntan 2007 & Stroke cohort, no dementia cases \\
\hline Anderson 2005 & $\begin{array}{l}\text { Non-RCT } \\
\text { Case-control study, } 222 \text { participants ( } 70 \text { with mild AD, } 152 \text { controls) compared composite neuropsycho- } \\
\text { logical test scores and simulated driving performance with prospective crash rate }\end{array}$ \\
\hline Anstey 2009 & $\begin{array}{l}\text { Non-RCT } \\
\text { Only } 2 \text { people with probable dementia included }\end{array}$ \\
\hline ANZSGM 2010 & $\begin{array}{l}\text { Non-RCT } \\
\text { Position statement }\end{array}$ \\
\hline Arai 2009 & Non-RCT \\
\hline Badenes 2007 & $\begin{array}{l}\text { Non-RCT } \\
\text { Case control study, } 187 \text { participants, ( } 92 \mathrm{MCI}, 55 \text { mild dementia, } 40 \text { controls) recruited from hospital } \\
\text { population, compared neuropsychological testing with ASDE-driver test (a Spanish office-based measure of } \\
\text { fitness to drive measuring: estimations of speed, coordination, reaction time, attention and concentration) }\end{array}$ \\
\hline Badenes-Guia 2008 & $\begin{array}{l}\text { Non-RCT } \\
92 \text { MCI, } 55 \text { mild dementia, } 40 \text { controls, tested with RBANS, TMT, Kohs block design compared with } \\
\text { ASDE-driver test and UFOV. No on-road test }\end{array}$ \\
\hline Ball 2006 & $\begin{array}{l}\text { Non-RCT } \\
\text { Population-based older driver cohort, no dementia measures included. } 2114 \text { older drivers compared initial } \\
\text { assessment (measures of vision, gross and fine motor skills and cognitive testing) with 4-5 years' follow-up } \\
\text { for motor vehicle accidents }\end{array}$ \\
\hline Barrash 2010 & $\begin{array}{l}\text { Non-RCT } \\
\text { Prospective study, self selected, advert respondents, } 24 \text { healthy, } 26 \text { probable AD, } 33 \text { PD. All active drivers } \\
\text { with MMSE }>26 \text {. People with AD and PD recruited from registry, used neuropsychological tests and on- } \\
\text { road, unable to blind assessors (PD). Differences on neuropsychological tests but not road test failure. Scores } \\
\text { did correlate with number of driving errors but effect diminished by demographic adjustments }\end{array}$ \\
\hline Berndt 2008 & $\begin{array}{l}\text { Non-RCT } \\
\text { Road test results in } 117 \text { people with dementia stratified by CDR score. Higher road test failure rate in higher } \\
\text { CDR score }\end{array}$ \\
\hline Breen 2007 & $\begin{array}{l}\text { Non-RCT } \\
\text { Review article }\end{array}$ \\
\hline
\end{tabular}


(Continued)

\begin{tabular}{ll}
\hline Brown 2005 & $\begin{array}{l}\text { Non-RCT } \\
\text { Case-control study, 75 participants (50 with mild to moderate AD, 25 controls) correlated neuropsychological } \\
\text { tests with rating of safe or unsafe in on-road testing }\end{array}$ \\
\hline Bylsma 1990 & Duplicate of Rebok 1994 \\
\hline Bylsma 1997 & $\begin{array}{l}\text { Non-RCT } \\
\text { Review article }\end{array}$ \\
\hline Carr 2000 & $\begin{array}{l}\text { Non-RCT } \\
\text { Retrospective case-control study of } 121 \text { participants (63 with mild Ad and } 58 \text { controls) comparing state- } \\
\text { recorded crash rates in both groups over the previous } 5 \text { years }\end{array}$ \\
\hline Carr 2011 & $\begin{array}{l}\text { Non-RCT } \\
99 \text { people with dementia referred for road test. Washington road test compared with visual, motor and } \\
\text { cognitive test. no information on dementia subtype or severity }\end{array}$ \\
\hline Clark 2005 & $\begin{array}{l}\text { Non RCT } \\
\text { Cross-sectional study of } 55 \text { participants (41 with Ad, } 6 \text { with VaD, } 2 \text { with DLB, } 4 \text { with FTD and } 2 \text { age- } \\
\text { associated memory loss) no controls. Correlated neuropsychological tests with a rating of safe or unsafe in } \\
\text { on-road testing }\end{array}$ \\
\hline
\end{tabular}

Cooper $1993 \quad$ Non-RCT

Case-control study comparing retrospective crash rates of 165 older people from a dementia clinic with a random sample from the population of drivers in British Columbia

Cotrell $1999 \quad$ Non-RCT

Cross-sectional study of 35 people with AD (only 19 still driving), evaluated on MMSE, driving status and carer assessment of driving behaviour

Cox $1998 \quad$ Non-RCT

Cross-sectional study of 50 participants (29 with AD) comparing neuropsychological tests with simulated drive

Cushman $1992 \quad$ Non-RCT

Case-control study of 17 participants (8 with possible dementia, 9 without suspected dementia) comparing neuropsychological tests with a rating of safe or unsafe in on-road testing

Daiello $2010 \quad$ Non-RCT

24 early $\mathrm{AD}$ before and after cholinesterase inhibitor treatment, compared on computerised tests of visual attention and executive function. Also 35 early AD treated vs. matched non-treated. NO ROAD TEST. Simulated computer-based drive. Cholinesterase inhibitor improved simulated drive and visual attention

Dawson $2009 \quad$ Non-RCT

Case control, comparing 40 early AD vs. 115 healthy people on cognitive, visual, motor and driving tests. $\mathrm{AD}$ had more driving errors 42 vs. 33. Errors associated with older age, lower cognition status, and poorer performance on BVRT, CFT-copy, TMT-A and functional reach test

Driving assessment for maintaining mobility and safety in drivers with dementia (Review) 
Devos $2007 \quad$ Non-RCT

Case-control study of 80 participants (40 people with Parkinson's disease and 40 controls). Included 11 people with PD and 3 controls with very mild cognitive decline (CDR 0.5). Participants were assessed using a driving simulator, driving history survey and the CDR. The people with PD also underwent a clinical test battery and an evaluation of fitness to drive performed by an official centre, which included visual, cognitive and on-road tests

Dobbs $1997 \quad$ Non-RCT

Case-control study of 115 older drivers with cognitive decline - mostly AD compared with 35 older and 23 younger controls. Comparisons made with cognitive testing and on-road driving test

Drachman $1993 \quad$ Non-RCT

Retrospective questionnaire-based survey comparing annual rates of occurrence and severity of all crashes based on responses of the carers of 130 people with $\mathrm{AD}$ and 112 age-matched control subjects (no dementia) and their spouses

Dubinsky $1992 \quad$ Non-RCT

Retrospective questionnaire based survey of 67 people with $\mathrm{AD}$ and their families and compared them with 100 elderly, non-spousal controls focused on driving habits, continued driving and the number of accidents per year for the past 10 years

Duchek $2003 \quad$ Non-RCT

Prospective case control study following 108 participants ( 50 with $\mathrm{AD}$ and 58 non-dementia) with sequential on-road testing

Ernst $2010 \quad$ Non-RCT

Carer interviews, 30 FTD, 26 AD. Reported differences in driving behaviour: AD: unsteady driving style, FTD: aggressive/ risky/lack of insight. 37\% MVA vs. 19\% for AD (NS)

Fitten $1995 \quad$ Non-RCT

Case-control study of 84 participants ( 15 with $\mathrm{AD}, 12$ with $\mathrm{VaD}$ and 57 non-dementia subjects). Correlated neuropsychological tests with Sepulveda Road test score and retrospective crash and violation rate

Fox $1997 \quad$ Non-RCT

Cross-sectional study of 19 participants with $\mathrm{AD}$, correlating road test with physician and neuropsychologist's assessment of fitness to drive and neuropsychological scores

Friedland $1988 \quad$ Non-RCT

Case-control study comparing retrospective crash rate of 30 people with $\mathrm{AD}$ with 20 people without dementia

Frittelli $2009 \quad$ Non-RCT

CCT comparing $20 \mathrm{AD}$ (CDR 1), $20 \mathrm{MCI}$ (CDR 0.5) and 19 healthy on computer-based driving simulator (STISTIM). All active drivers and not on treatment for AD. Poorer performance on length of run, mean time to collisions, off-road events in $\mathrm{AD}$ vs. MCI and controls. MCI shorter time to collisions than healthy

Driving assessment for maintaining mobility and safety in drivers with dementia (Review) 


\begin{tabular}{ll} 
Gilley 1991 & $\begin{array}{l}\text { Non-RCT } \\
\text { Retrospective survey of } 522 \text { people and their collateral informants from a dementia clinic. Only } 322 \text { licensed } \\
\text { to drive at onset of dementia and } 93 \text { active drivers at time of questionnaire. Questionnaire on driving cessation } \\
\text { and unsafe driving in previous } 6 \text { months }\end{array}$ \\
\hline Grace 2005 & $\begin{array}{l}\text { Non-RCT } \\
21 \text { mild AD, } 21 \text { PD without dementia and } 21 \text { healthy controls. Compared neuro-psychological tests and on- } \\
\text { road driving test, miles driven AD }<\text { PD }<\text { N. Poorer performance on neuro-psychological testing correlated } \\
\text { with unsafe or marginal performance. HVLT for AD and PD, TMT-A for AD. Hoehn and Yahr correlated } \\
\text { with marginal driving performance }\end{array}$ \\
\hline
\end{tabular}

$\begin{array}{ll}\text { Hunt } 1993 & \text { Non-RCT } \\ \text { Case-control study of } 38 \text { participants (25 with AD, } 13 \text { without suspected dementia). Correlated neuropsy- } \\ \text { chological tests with a rating of safe or unsafe in on-road testing }\end{array}$

\begin{tabular}{ll}
\hline Hunt 1997 & $\begin{array}{l}\text { Non-RCT } \\
\text { Case-control study of } 94 \text { participants ( } 56 \text { with AD, } 38 \text { without suspected dementia). Correlated neuropsy- } \\
\text { chological tests with a rating of safe or unsafe in on-road testing }\end{array}$
\end{tabular}

$\begin{array}{ll}\text { Hunt } 2010 & \begin{array}{l}\text { Non-RCT } \\ \text { Observational retrospective cohort }\end{array}\end{array}$

\begin{tabular}{|c|c|}
\hline Innes 2005 & $\begin{array}{l}\text { Non-RCT } \\
\text { Cross-sectional study of } 50 \text { drivers with neurological disorders ( } 4 \text { with AD) referred to a Driving and Vehicle } \\
\text { Assessment Service comparing a battery of computerised sensory-motor and cognitive tests and on-road } \\
\text { driving assessment. Developed a model of sensory-motor and cognitive tests that would predict pass or fail } \\
\text { on-road testing }\end{array}$ \\
\hline Iverson 2010 & $\begin{array}{l}\text { Non-RCT } \\
\text { Consensus statement }\end{array}$ \\
\hline Johansson 1997 & $\begin{array}{l}\text { Non-RCT } \\
\text { Review article }\end{array}$ \\
\hline Kamimura 2009 & Non-RCT \\
\hline Kawano 2009 & $\begin{array}{l}\text { Non-RCT } \\
\text { Observational retrospective study }\end{array}$ \\
\hline Kay 2009 & $\begin{array}{l}\text { Non-RCT } \\
\text { Prospective multicentre study of } 115 \text { driving assessment referrals with functional impairment } 96 \text { neurological } \\
\text { including } 30 \mathrm{AD} \text {. Compared } 2 \text { standardised office tests with on-road assessment. Cut-offs for both scores } \\
\text { predicted road test fail }\end{array}$ \\
\hline Lafont 2010 & $\begin{array}{l}\text { Non-RCT } \\
\text { Prospective population study } 2104 \text { participants, predictors of driving cessation, including neuro-psycho- } \\
\text { logical testing and dementia diagnosis. Dementia associated with driving cessation but not with crashes. }\end{array}$ \\
\hline
\end{tabular}


Development of dementia later in the study was associated with crashes (OR 3.4). Poor performance on TMT-B associated with crashes (OR 7.7)

\begin{tabular}{|c|c|}
\hline Laks 1999 & $\begin{array}{l}\text { Non-RCT } \\
\text { Review article }\end{array}$ \\
\hline Laks 2000 & $\begin{array}{l}\text { Non-RCT } \\
\text { Survey of cognitive performance and driving history (licensing and cessation) in } 110 \text { residents of sheltered } \\
\text { accommodation for older people }\end{array}$ \\
\hline Leproust 2008 & $\begin{array}{l}\text { Non-RCT } \\
\text { Hypothetical study. Suggested on-road testing every } 3 \text { years for people over } 85 \text { years of age as preventing } 569 \\
\text { crashes and inducing } 270 \text { adverse events. Based on crash risk or } 2.0 \text { for drivers with dementia }\end{array}$ \\
\hline Lincoln 2006 & $\begin{array}{l}\text { Non-RCT } \\
\text { Case-control study of } 75 \text { participants ( } 42 \text { with dementia, } 33 \text { without suspected dementia). Correlated neu- } \\
\text { ropsychological tests with a rating of safe or unsafe in on-road testing. An algorithm to predict road-test } \\
\text { failure was generated from the neuropsychological tests and validated on a cohort of } 17 \text { people with dementia }\end{array}$ \\
\hline Lincoln 2010 & $\begin{array}{l}\text { Non-RCT } \\
\text { Dementia cohort of } 75 \text { people with } 34 \mathrm{AD}, 14 \mathrm{VaD}, 2 \mathrm{DLB}, 1 \mathrm{FTD}, 1 \mathrm{MCI}, 4 \text { mixed - } 65 \text { had on-road } \\
\text { test. Dementia severity not recorded. } 12 \text { failed road test. Combination cognitive scoring gave sensitivity } 80 \% \\
\text { and specificity } 61.5 \% \text { for predicting road test failure. Validated previous prediction rule correctly classifying } \\
76 \% \text { of people }\end{array}$ \\
\hline Love 2007 & Non-RCT \\
\hline Lucas-Blaustein 1988 & $\begin{array}{l}\text { Non-RCT } \\
\text { Retrospective survey of driving history and crashes in } 72 \text { people referred to a dementia clinic }\end{array}$ \\
\hline Lukas 2009 & $\begin{array}{l}\text { Non-RCT } \\
\text { Review article }\end{array}$ \\
\hline Man-Son-Hing 2007 & $\begin{array}{l}\text { Non-RCT } \\
\text { Review article }\end{array}$ \\
\hline Meuser 2006 & $\begin{array}{l}\text { Non-RCT, } \\
\text { Trial of education for health professionals }\end{array}$ \\
\hline Meuser 2009 & $\begin{array}{l}\text { Non-RCT } \\
\text { Driving outcomes of reported impaired drivers in Missouri. Reporting resulted in lower crash rate and } \\
\text { mortality in reported drivers }-96.5 \% \text { had license revoked }\end{array}$ \\
\hline Molnar 2006 & $\begin{array}{l}\text { Non-RCT } \\
\text { Review article }\end{array}$ \\
\hline Molnar 2007 & $\begin{array}{l}\text { Non-RCT } \\
\text { Review article }\end{array}$ \\
\hline
\end{tabular}


(Continued)

\begin{tabular}{|c|c|}
\hline Mosimann 2011 & $\begin{array}{l}\text { Non-RCT } \\
\text { Consensus statement }\end{array}$ \\
\hline Neitch 2011 & $\begin{array}{l}\text { Non-RCT } \\
\text { Retrospective audit of } 43 \text { assessments comparing performance on standardised testing of } 27 \text { with and } 25 \\
\text { without dementia }\end{array}$ \\
\hline O'Connor 2010 & $\begin{array}{l}\text { Non-RCT } \\
\text { More rapid decline in life space and driving in MCI vs. healthy controls, no driving assessment }\end{array}$ \\
\hline Odenheimer 1994 & $\begin{array}{l}\text { Non-RCT } \\
\text { Cross-sectional study of } 30 \text { licensed drivers with a broad range of cognitive skills ( } 3 \text { with AD, } 3 \text { with VaD), } \\
\text { over age } 60 \text { years, were road tested on a closed course and in traffic by a driving instructor and } 2 \text { researchers. } \\
\text { Driving instructor scores and cognitive test scores compared with research road test scores }\end{array}$ \\
\hline Okonkwo 2009 & $\begin{array}{l}\text { Non-RCT } \\
\text { Case-control study comparing } 57 \mathrm{MCI} \text { vs. } 68 \text { healthy controls, on-road test as part of functional assessment. } \\
70 \% \text { vs. } 50 \% \text { had some difficulty on road test, non-significant difference in tendency to overestimate ability. } \\
\text { No reported test failures }\end{array}$ \\
\hline Oswanski 2007 & $\begin{array}{l}\text { Non-RCT } \\
\text { Cross-sectional study of } 232 \text { drivers over } 55 \text { years referred for license renewal were given the Motor Free } \\
\text { Visual Perceptual Test, clock test, and an on-road driving test. No dementia diagnosis included }\end{array}$ \\
\hline Ott 2005 & $\begin{array}{l}\text { Non-RCT } \\
\text { Cross-sectional study of } 50 \text { drivers with probable or possible AD (very mild to mild), from a longitudinal } \\
\text { study of driving and dementia to compare office-based clinician rating of driving competence with on-road } \\
\text { assessment. Clinician rated the drivers as safe, marginal or unsafe (based on chart review) and compared these } \\
\text { ratings with total driving scores on a standardised road test and categorical ratings of driving competence } \\
\text { from a professional driving instructor }\end{array}$ \\
\hline
\end{tabular}

Ott $2008 \quad$ Non-RCT

CCT: 65 probable $\mathrm{AD}, 23$ possible $\mathrm{AD}(53 \mathrm{CDR}$ 0.5, 35 CDR 1 ) and 45 healthy controls. In AD cases with CDI 0.5-1 maze test and neuropsychological test were compared to on-road testing. Road test failure noted in $1 / 45$ controls and $17 / 88 \mathrm{AD}$. Road test score correlated with maze and neuropsychological tests

\begin{tabular}{ll} 
Parker 2000 & $\begin{array}{l}\text { Non-RCT } \\
\text { Questionnaire survey of } 1989 \text { drivers aged } 50 \text { years or over (Manchester Driver Behavior Questionnaire) } \\
\text { examined factors associated with crashes in older drivers. No dementia diagnosis }\end{array}$ \\
\hline Patomella 2010 & $\begin{array}{l}\text { Non-RCT } \\
205 \text { impaired drivers referred for on-road test. } 128 \text { had stroke, } 43 \text { with MCI and } 34 \text { with dementia }\end{array}$ \\
\hline Rapoport 2007 & $\begin{array}{l}\text { Non- RCT } \\
\text { Review article }\end{array}$ \\
\hline Rebok 1994 & $\begin{array}{l}\text { Non-RCT } \\
\text { Case-control study of } 22 \text { older drivers (10 with AD and } 12 \text { controls) compared on neuro-psychological tests, }\end{array}$
\end{tabular}

Driving assessment for maintaining mobility and safety in drivers with dementia (Review) 
the Driver Performance test (subjects answer questions based on videotaped driving scenarios) and Driver Advisement System (computer-based measures of reaction time and coordination using steering wheel and pedals in front of monitor)

\begin{tabular}{ll}
\hline Reger 2004 & $\begin{array}{l}\text { Non-RCT } \\
\text { Review article }\end{array}$ \\
\hline Regtuijt 2007 & $\begin{array}{l}\text { Non-RCT } \\
\text { Case report }\end{array}$ \\
\hline Rizzo 1997 & $\begin{array}{l}\text { Non-RCT } \\
\text { Case-control study of 39 drivers (21 with AD and } 18 \text { controls) comparing neuro-psychological testing with } \\
\text { driving simulator performance and simulator crash rate }\end{array}$ \\
\hline Rizzo 2001 & $\begin{array}{l}\text { Non-RCT } \\
\text { Same design and participants as Rizzo } 1997 \text { but with hazards at intersections requiring rapid response to } \\
\text { avoid crash }\end{array}$ \\
\hline Ross 2009 & $\begin{array}{l}\text { Non-RCT } \\
\text { Pooled data from } 9 \text { longitudinal studies in ageing, } 5206 \text { older adults no intervention, no assessment of driving } \\
\text { ability }\end{array}$ \\
\hline Silva 2009 & $\begin{array}{l}\text { Non-RCT } \\
\text { Review article }\end{array}$ \\
\hline
\end{tabular}

Ningh 2007
Cross-sectional study of 154 individuals with PD ( 22 with dementia: diagnosed by team consensus based
on MMSE, 15 road sign recognition, visuospatial construction, Trail Making test, forward and reverse digit
span, and a story recall) referred to a driving assessment centre. Group included 17 who stated that they had
stopped driving by themselves before assessment. Driving ability determined by a combination of clinical
tests, reaction times on a static test rig and an in-car driving test

Snellgrove $2000 \quad$ Non-RCT

Cross-sectional study of 115 community-dwelling older drivers with MCI or early dementia (recruited through a memory clinic). Participants completed the Maze Task, and immediately thereafter, a standardised on-road driving test. Results also compared with cognitive tests from memory clinic

Snyder $2009 \quad$ Non-RCT

Retrospective audit of 1664 impaired drivers mandatorily reported, $88 \%$ had cognitive impairment, reported by internists and general practitioners. Auto suspension all - 15\% requested re-test, $3 \%$ contested and only $10 \%$ regained driving privileges. No data on impact on crashes or cessations

Soderstrom $2009 \quad$ Non-RCT

Retrospective audit of reasons for referral by police to medical advisor boards. $40 \%$ of all referrals for confusion disorientation but dementia only in $3 \%$

Staplin $2003 \quad$ Non-RCT

Same as Staplin 2003a with further 1-year follow-up data for crashes 
(Continued)

\begin{tabular}{|c|c|}
\hline Staplin 2003a & $\begin{array}{l}\text { Non-RCT } \\
\text { Prospective cohort study of } 2500 \text { drivers over } 55 \text { years of age comparing cognitive and motor performance } \\
\text { with prospective crash rate over } 2 \text { years following assessment. No dementia diagnosis }\end{array}$ \\
\hline Stutts 1998 & $\begin{array}{l}\text { Non-RCT } \\
\text { Retrospective cohort study of } 3238 \text { drivers aged } 65 \text { years and older applying for renewal of their driver's } \\
\text { license. Compared cognitive assessments with crash involvement during the } 3 \text {-year period prior to testing. } \\
\text { No dementia diagnosis }\end{array}$ \\
\hline Szlyk 2002 & $\begin{array}{l}\text { Non-RCT } \\
\text { Initial survey of } 292 \text { licensed neuropsychologists on neuropsychological tests currently used to screen people } \\
\text { for driving. Followed by development of } 12 \text {-item neuropsychological battery used to screen } 22 \text { licensed } \\
\text { drivers ranging in age from } 67 \text { to } 91 \text { years. Subjects were administered the neuropsychological battery, a } \\
\text { driving simulator test and a Driving Habits Interview. No dementia diagnosis (subject classified as suspected } \\
\text { dementia based on MMSE }<24 \text { ) }\end{array}$ \\
\hline Taylor 2001 & $\begin{array}{l}\text { Non-RCT } \\
\text { Survey of } 922 \text { drivers whose licenses had been revoked or suspended due to dementia or suspected dementia. } \\
\text { Questioned on the changes in household travel patterns and responsibilities following license revocation and } \\
\text { on the psychological effects of these changes on affected household members. The survey was addressed to } \\
\text { and in nearly all cases completed by the 'carer' of the former driver }\end{array}$ \\
\hline Trilling 2001 & $\begin{array}{l}\text { Non-RCT } \\
\text { Review article }\end{array}$ \\
\hline Trobe 1996 & $\begin{array}{l}\text { Non-RCT } \\
\text { Retrospective case-control study of } 143 \text { licensed people with AD and } 715 \text { licensed comparison subjects } \\
\text { matched } 5 \text { to } 1 \text { in age ( } \pm 6 \text { years), sex and county of residence. Compared crashes and violations from } \\
\text { state driving records with neuropsychological test scores. A questionnaire-based inquiry on the influence of } \\
\text { physician, family and state interventions on driving cessation was administered }\end{array}$ \\
\hline Tuokko 1995 & $\begin{array}{l}\text { Non-RCT } \\
\text { Retrospective case-control study of } 249 \text { people referred to an outpatient dementia clinic. People were divided } \\
\text { into those who met criteria for dementia and those who did not and compared with controls for retrospective } \\
\text { crash and traffic violation rate. For each group, control subjects matched on age, gender and location of } \\
\text { residence were randomly selected from the records of all drivers in the province }\end{array}$ \\
\hline
\end{tabular}

Uc $2005 \quad$ Non-RCT

Case-control study of 33 drivers with probable AD of mild severity and 137 neurologically normal older adults comparing a battery of visual and cognitive tests in addition to driving safety and detection of specific landmarks and traffic signs along a segment of an on-road experimental drive

Uc $2006 \quad$ Non-RCT

Case-control study of 61 drivers with mild AD and 115 elderly controls using a driving simulator comparing crash rate and unsafe avoidance behaviour in a driving situation with a high risk of rear end collision 
(Continued)

\begin{tabular}{ll}
\hline Vaux 2010 & $\begin{array}{l}\text { Non-RCT } \\
\text { Prospective case control study: } 8 \text { people with PD, } 6 \text { with AD and } 18 \text { healthy controls. Simulated drive on } \\
\text { desktop computer tasked to identify whether moving spheres on a collisions course with them }\end{array}$ \\
\hline Wadley 2009 & $\begin{array}{l}\text { Non-RCT } \\
\text { Prospective case control stud: } 46 \mathrm{MCI} \text { vs. } 59 \text { healthy controls compared on driving. MCI had more "less } \\
\text { than optimal" performance on global measures but not outright fail }\end{array}$ \\
\hline Wild 2003 & $\begin{array}{l}\text { Non-RCT } \\
\text { Case-control study of } 15 \text { drivers with mild AD and } 15 \text { controls comparing questionnaire responses on self } \\
\text { reported cognitive function and driving performance in addition to an on-road test }\end{array}$ \\
\hline Withaar 2000 & $\begin{array}{l}\text { Non-RCT } \\
\text { Review article }\end{array}$ \\
\hline Woolf 2006 & $\begin{array}{l}\text { Non-RCT } \\
\text { Review article }\end{array}$ \\
\hline Zuin 2002 & $\begin{array}{l}\text { Non-RCT } \\
\text { Retrospective case control study of } 56 \text { drivers with dementia (43 probable AD, } 6 \text { possible AD, } 3 \text { VaD, } 1 \text { DLB, } \\
\text { 2 FTD, } 1 \text { unclassified). and } 31 \text { elderly controls. Motor vehicle crash and abnormal driving behaviour rates } \\
\text { obtained from collateral informants and compared with detailed neurological, psychiatric and neuropsycho- } \\
\text { logical examinations }\end{array}$ \\
\hline
\end{tabular}

AD: Alzheimer's dementia; ASDE: Proprietory: Manufacturers name "General ASDE, SA" ; BVRT: Benton Visual Retention Test; CCT: controlled clinical trial; CDR: Clinical Dementia Rating; CFT: Complex Figure Test; DLB: dementia with Lewy body; FTD: fronto-temporal dementia; HVLT: Hopkins Verbal Learning Test; MCI: mild cognitive impairment; MMSE: Mini-Mental State Examination; MVA: motor vehicle accident; NS: not significant; OR: odds ratio; PD: Parkinson's disease; RBANS: Repeatable Battery for the Assessment of Neuropsychological Status.; RCT: Randomised Controlled Trial ; TMT: Trail-Making Test ; UFOV: Useful Field of VIew; VaD: vascular dementia. 


\section{DATA ANDANALYSES}

This review has no analyses.

\section{AP PENDICES}

\section{Appendix I. Search: September 2012}

\begin{tabular}{l|l|l}
\hline Source & Search strategy & Hits retrieved \\
\hline 1. ALOIS (www.medicine.ox.ac.uk/alois) & $\begin{array}{l}\text { driving OR car OR cars OR driver OR } \\
\text { drivers OR automobile OR vehicle }\end{array}$ \\
\hline
\end{tabular}

2. MEDLINE In-process and other nonindexed citations and MEDLINE 1950present (Ovid SP)

1. exp Dementia/

2. Delirium/

3. Wernicke Encephalopathy/

4. Delirium, Dementia, Amnestic, Cognitive Disorders/

5. dement*.mp.

6. alzheimer*.mp.

7. (lewy* adj2 bod*).mp.

8. deliri*.mp.

9. (chronic adj2 cerebrovascular).mp.

10. ("organic brain disease" or "organic brain syndrome").mp

11. ("normal pressure hydrocephalus" and "shunt*").mp.

12. "benign senescent forgetfulness".mp.

13. (cerebr* adj2 deteriorat*).mp.

14. (cerebral* adj2 insufficient $\left.{ }^{*}\right)$.mp.

15. (pick* adj2 disease).mp.

16. (creutzfeldt or jcd or cjd).mp.

17. huntington*.mp.

18. binswanger*.mp.

19. korsako*.mp.

20. or/1-19

21. (motor adj2 vehicle*).ti,ab.

22. (automobile adj2 driving).ti,ab.

23. (automobile adj2 driver*).ti,ab.

24. (car adj2 driver*).ti,ab.

25. (traffic adj2 accident*).ti,ab.

26. (car adj2 accident*).ti,ab.

27. Accidents, Traffic/ or Automobile Driv- 
ing/

28. (driving and (asess* or continu* or capabilit*)).ti,ab.

29. or $/ 21-28$

30. 20 and 29

31. randomized controlled trial.pt.

32. controlled clinical trial.pt.

33. randomized.ab.

34. placebo.ab.

35. randomly.ab.

36. trial.ab.

37. groups.ab.

38. or/31-37

39. 30 and 38

40. $\left(2007^{*}\right.$ or $2008^{*}$ or $2009^{*}$ or $2010^{*}$ or $2011^{*}$ or $\left.2012^{*}\right)$.ed.

41.39 and 40

3. EMBASE

1974-2012 September 07 (Ovid SP)
1. exp dementia/

2. Lewy body/

3. delirium/

4. Wernicke encephalopathy/

5. cognitive defect/

6. dement*.mp.

7. alzheimer*.mp.

8. (lewy* adj2 bod*).mp.

9. deliri*.mp.

10. (chronic adj2 cerebrovascular).mp.

11. ("organic brain disease" or "organic brain syndrome").mp

12. "supranuclear palsy".mp.

13. ("normal pressure hydrocephalus" and “shunt*").mp.

14. "benign senescent forgetfulness".mp.

15. (cerebr* adj2 deteriorat*).mp.

16. (cerebral* adj2 insufficient $\left.{ }^{*}\right) . m p$.

17. (pick* adj2 disease).mp.

18. (creutzfeldt or jcd or cjd).mp.

19. huntington*.mp.

20. binswanger*.mp.

21. korsako*.mp.

22. CADASIL.mp.

23. or/1-22

24. (motor adj2 vehicle*).ti,ab.

25. (automobile adj2 driving).ti,ab.

26. (automobile adj2 driver*).ti,ab.

27. (car adj 2 driver*).ti,ab.

28. (traffic adj2 accident*).ti,ab. 
29. (car adj2 accident*).ti,ab.

30. (driving and (asess* or continu* or capabilit* or evaluat*)).ti,ab

31. car driving/ or driving ability/ or traffic accident/

32. or/24-31

33. 23 and 32

34. randomized controlled trial/

35. controlled clinical trial/

36. placebo.ab.

37. trial.ti,ab.

38. randomly.ab.

39. groups.ab.

40. (RCT or CCT).ti,ab.

41. randomi?ed.ab.

42. or/34-41

43. 33 and 42

44. $\left(2007^{*}\right.$ or $2008^{*}$ or $2009^{*}$ or $2010^{*}$ or

$2011^{*}$ or $\left.2012^{*}\right)$.em.

45.43 and 44

4. PsycINFO

1806-July week 12012 (Ovid SP)
1. exp Dementia/

2. $\exp$ Delirium/

3. exp Huntingtons Disease/

4. exp Kluver Bucy Syndrome/

5. exp Wernickes Syndrome/

6. exp Cognitive Impairment/

7. dement*.mp.

8. alzheimer*.mp.

9. (lewy* adj2 bod*).mp.

10. deliri*.mp.

11. (chronic adj2 cerebrovascular).mp.

12. ("organic brain disease" or "organic brain syndrome").mp

13. "supranuclear palsy".mp.

14. ("normal pressure hydrocephalus" and "shunt").mp.

15. "benign senescent forgetfulness”.mp.

16. (cerebr* adj2 deteriorat $\left.{ }^{*}\right)$.mp.

17. (cerebral* adj 2 insufficient* ${ }^{*}$.mp.

18. (pick* adj2 disease).mp.

19. (creutzfeldt or jcd or cjd).mp.

20. huntington*.mp.

21. binswanger*.mp.

22. korsako*.mp.

23. ("parkinson* disease dementia" or PDD

or "parkinson* dementia").mp

24. or/1-23 
25. (motor adj2 vehicle*).ti,ab.

26. (automobile adj2 driving).ti,ab.

27. (automobile adj2 driver*).ti,ab.

28. (car adj2 driver ${ }^{*}$ ).ti,ab.

29. (traffic adj2 accident*).ti,ab.

30. (car adj2 accident*).ti,ab.

31. (driving and (asess* or continu* or capabilit* or evaluat*)).ti,ab

32. exp Driving Behavior/ or exp Motor Vehicles/

33. or $/ 25-32$

34.24 and 33

35 . $\left(2007^{*}\right.$ or $2008^{*}$ or $2009^{*}$ or $2010^{*}$ or $2011^{*}$ or $\left.2012^{*}\right)$.up.

36.34 and 35

37. randomi?ed.ab.

38. exp Clinical Trials/

39. randomly.ab.

40. (RCT or CCT).ti,ab.

41. groups.ab.

42. ("double-blind"” or "single-blind").ti, ab.

43. placebo.ab.

44. trial.ti,ab.

45. or/37-44

46. 36 and 45 orders")

S3 (MH "Wernicke's Encephalopathy")

S4 TX dement*

S5 TX alzheimer*

S6 TX lewy* N2 bod*

S7 TX deliri*

S8 TX chronic N2 cerebrovascular

S9 TX "organic brain disease" or "organic brain syndrome"

S10 TX "normal pressure hydrocephalus" and "shunt*"

S11 TX "benign senescent forgetfulness"

S12 TX cerebr* N2 deteriorat*

S13 TX cerebral* N2 insufficient*

S14 TX pick* N2 disease

S15 TX creutzfeldt or jcd or cjd

S16 TX huntington*

S17 TX binswanger* 


\author{
S18 TX korsako* \\ $\mathrm{S} 19 \mathrm{~S} 1$ or $\mathrm{S} 2$ or $\mathrm{S} 3$ or $\mathrm{S} 4$ or $\mathrm{S} 5$ or $\mathrm{S} 6$ or $\mathrm{S} 7$ \\ or $S 8$ or $S 9$ or $S 10$ or $S 11$ or $S 12$ or $S 13$ or \\ $\mathrm{S} 14$ or $\mathrm{S} 15$ or $\mathrm{S} 16$ or $\mathrm{S} 17$ or $\mathrm{S} 18$ \\ S20 (MH "Automobile Driving") OR \\ (MH "Drive") OR (MH "Automobile \\ Driver Examination") \\ S21 TX motor N2 vehicle* \\ S22 TX automobile N2 driving \\ S23 TX automobile adj2 driver* \\ S24 TX car N2 driver* \\ S25 TX traffic N2 accident* \\ S26 TX car N2 accident* \\ S27 TX driving N3 asess* \\ S28 TX driving N3 continu* \\ S29 TX driving N3 capabilit* \\ S30 TX driving N3 evaluat* \\ S31 S20 or S21 or S22 or S23 or S24 or \\ S25 or S26 or S27 or S28 or S29 or S30 \\ S32 S19 and S31 \\ S33 EM 2007 \\ S34 EM 2008 \\ S35 EM 2009 \\ S36 EM 2010 \\ S37 EM 2011 \\ S38 EM 2012 \\ S39 S33 or S34 or S35 or S36 or S37 or \\ S38 \\ S40 S32 and S39
}

Topic $=($ dement* OR VCI OR "vascular cognitive impairment*" OR VaD OR alzheimer* OR AD) AND Topic=(driving OR car OR vehicle* OR cars OR automobile) AND Year Published $=(2007-2012)$ AND Topic=(randomly OR trial OR randomised OR randomized OR RCT OR "control* study" OR CCT OR placebo)

Timespan=All Years. Databases= SCI-EXPANDED, SSCI, A\&HCI, CPCI$\mathrm{S}$, CPCI-SSH

Lemmatization $=\mathrm{On}$

\section{LILACS (BIREME)}

conducción OR driving OR condução

OR car OR vehicle OR carro OR coche OR vehículo OR veículo [Words] and dementia OR demencia OR demência OR alzheimer OR alzheimers OR alzheimer's [Words] 


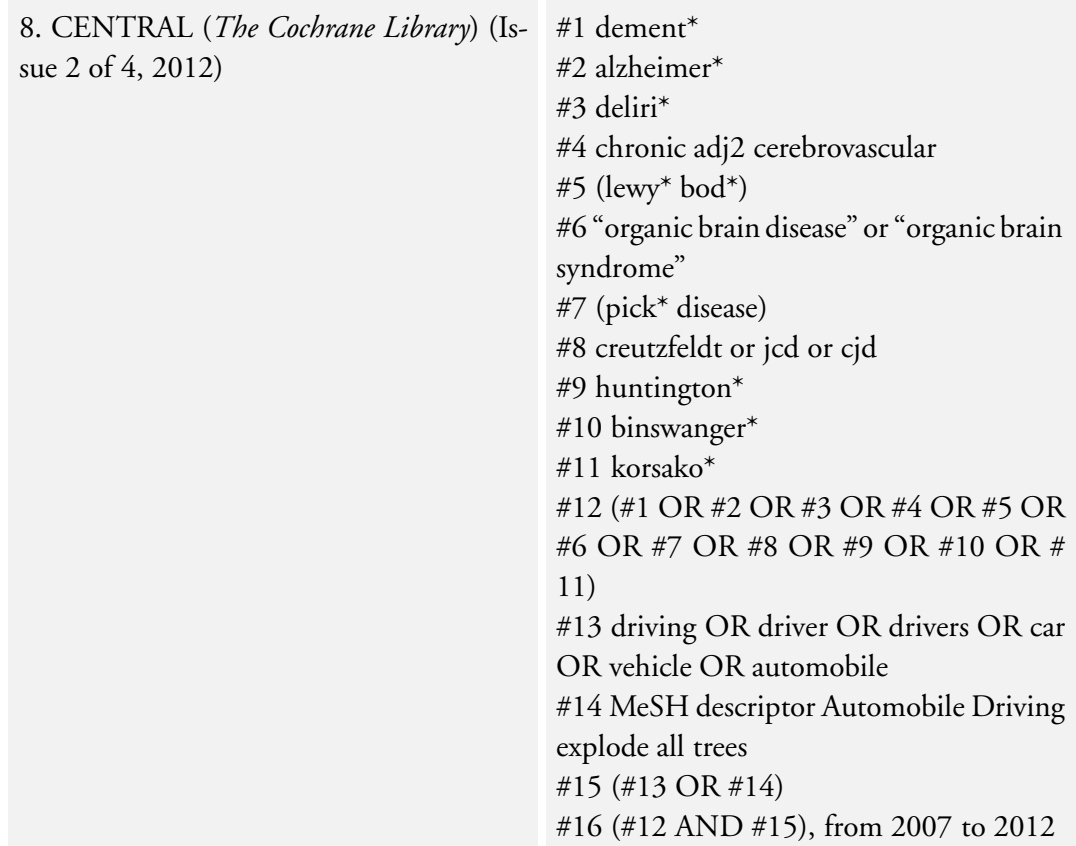

9. Clinicaltrials.gov www.clinicaltrials.gov) drive | Interventional Studies | dementia OR alzheimers OR AD OR alzheimer's OR alzheimer OR lewy OR FTLD OR FLD OR MCI OR cognitive OR cognition | received from $10 / 01 / 2007$ to $09 / 09 / 2012$

(dementia OR alzheimers OR AD OR 0 alzheimer's OR alzheimer OR lewy OR FTLD OR FLD OR MCI OR cognitive OR cognition) AND (driving OR driver) AND (2007-2012)

Registry; Clinical Trials Registry - India; Clinical Research Information Service - Republic of Korea; German Clinical Trials Register; Iranian Registry of Clinical Trials; Japan Primary Registries Network; Pan African Clinical Trial Registry; Sri Lanka Clinical Trials Registry; The Netherlands National Trial Register)

TOTAL before de-duplication and first assess 


\section{WHAT'S NEW}

Last assessed as up-to-date: 12 March 2013.

\begin{tabular}{lll}
\hline Date & Event & Description \\
\hline 8 April 2013 & New citation required but conclusions have not changed & Conclusions unchanged \\
\hline 13 March 2013 & New search has been performed & $\begin{array}{l}\text { An update search was performed for this review on 13 } \\
\text { September 2012 }\end{array}$ \\
\hline
\end{tabular}

\section{CONTRIBUTIONS OFAUTHORS}

Alan Martin and Desmond O'Neill wrote the study protocol and retrieved studies, assessed study quality, extracted and interpreted data, and wrote the discussion.

Richard Marottoli retrieved studies, assessed study quality, extracted and interpreted data as a third review author, compared and contrasted with AM and DON, and co-wrote the discussion.

Contact editor: Rupert McShane

Consumer editor: Aisling Lynch

\section{DECLARATIONSOF INTEREST}

None known.

\section{SOURCES OF SUPPORT}

\section{Internal sources}

- Department of Medicine for the Older Person, Mater Micericordiae University Hospital, Dublin 7, Ireland.

- Department of Age-Related Health Care, Adelaide and Meath Hospital, Dublin 24, Ireland.

- Department of Geriatrics, Yale University, New Haven, USA.

\section{External sources}

- No sources of support supplied 


\section{INDEX TERMS}

\section{Medical Subject Headings (MeSH)}

Accidents, Traffic [* prevention \& control]; Automobile Driving [* psychology]; Dementia [* psychology]; Safety

\section{MeSH check words}

Aged; Humans 